\title{
AN ACCOUNT OF AN ACQUISITION TRIP IN THE COUNTRIES OF SOUTHEAST ASIA
}

CECIL HOBBS

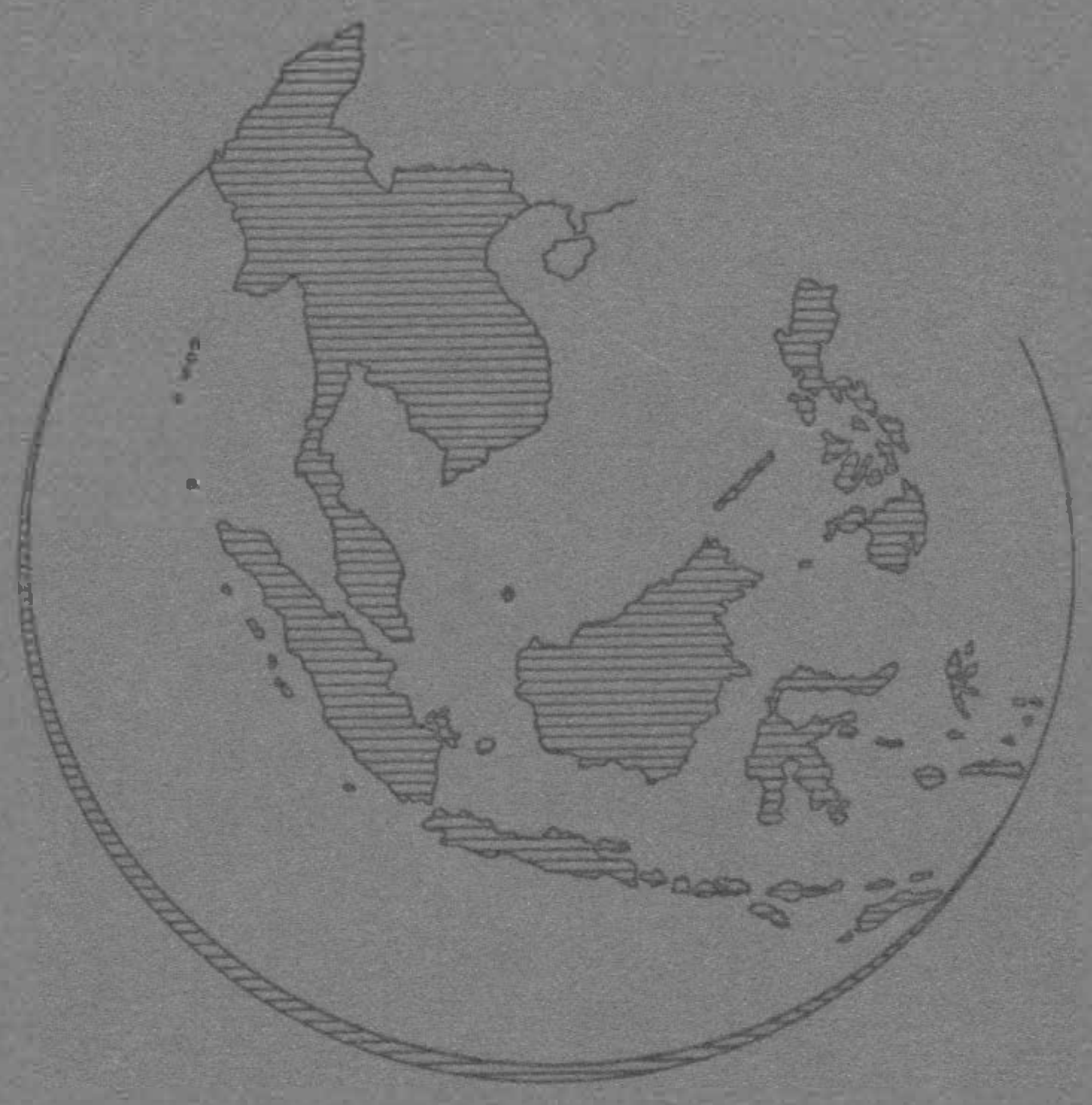

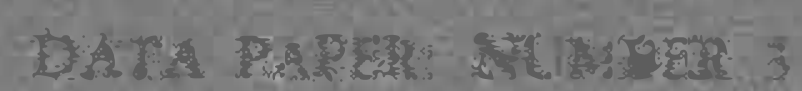

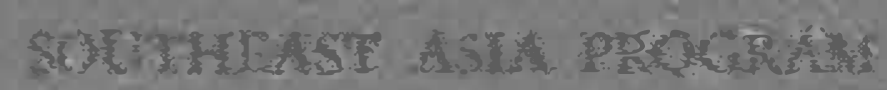

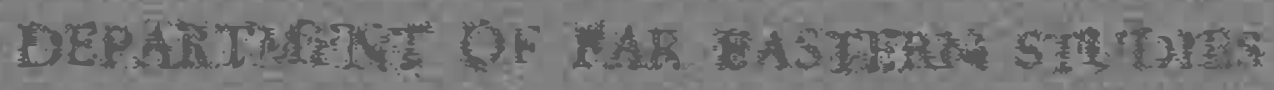
CORNAL UNTVREIT FERRE ARY 1053 
REPORT OF CECIL HOBBS ON THE TRIP TO SOUTHEAST ASIA

$* * * *$

On October 29, 1947 I left Washington by

Pan American Airways for the countries of Southeast fisia to assist in carrying out the Library's foreign acquisitions program. The trip extended for a period of six months and I returned on May 1, 1948.

Going by way of London, I was able to investigate a microfilm order for certain Malayan materials which had been requested from the Public Record Office. While in that city I saw Sargent Child, an old friend of Dr. Evans, who was in charge of the U.S. Information Servine Library. I was told that the Library's procedures and accessibility to the inquiring public have surprised both the Britiah libraries and the English people. While I was talking with Mr. Charles, the Information Officer of the Embassy, he related the valuable work which Mr. Toth had accomplished as Publications Procurement Officer. Miss Audrey Haskett was doing the best she could to carry on that function al ong with other duties.

The British Museum was making its transition from the war period. One merely had to step inside the building to see that the war had touched it too. In the absence of the Librarian, Sir John Forsdyke, who was attending the Mexico meetings of UNESCO, I met Mr. Francis, the Assistant Librariane who related the ways the Library had suffered from the war. I was disaprointed in not being able to see $D_{r}$. Lionel Barnett who is noted for his scholarly work in Burmese as well as certain languages of India. When I was being shown the Museum by Mr. Levine of the Oriental Department, all doors had to be unlocked from room to room for the museum $i_{\text {o }}$ actually closed to the publio with the exception of the central reading room. Even here entrance was permitted only to those with tickets of admission for research work only. After seeing tneir system of keeping acquisition records, I certainly prefer the rard system.

Before we left London, the flight was changed four times. The route was also chan sed so that a lae rge shipment of cholera serum could be taken from the United Nations World Health Relief Commission to Damascus for the cholera epidemic in various countries of the Near East. Leaving London on Sunday afternoon, flying via Paris, Rome, Istanbul, Damascus, Karachi, we arrived in Calcutta on Tuesday morning 
where I was detained four days due to faulty plane connections.

During the flight to Bangkok I was was interested to see the heavily wooded country of Burma and, although it was covered for long stretchese one was able to see parts of the Siam-Burma railroad--the "railroad of death"-which was constructed by Japanese war prisoners during the war. One of the passengers on the plane was one of those workmen who had been interned in that area. 


\section{SIAM}

On the afternoon of November 8, I arrived in Bangkok. The first evening was an eventful one. Dinner had been arranged for me at the residence of Ambassador and Mrs. Stanton. After dinner we proceeded to a special meeting of the Siam Research Society where we heard an interesting lecture by Prince Dhani Nivat on Siamese Dramatic Art and it's I'evelopment. Following the lecture there was a presentation of the old tjpe of Siamese shadow play and the more modern masked drama.

At the very time we were assembled in the Silpakorn Theater listening to Prince Dhanies lecture an event took place within the Government which will be a chapter in Siamese history, and possibly will change the whole Siamese political scene for some time to come. Shortly after midnight, tanks and armored cars rolled along some of the main streets and military detachments went to various parts of the city to search for certain government leaders. By the next morning it was evident that the military men were in complete control of the situation and effective power had come into their hands. It was announced by radio that a military group, headed by a certain promoter of the 1932 coup d'etat, had successfully staged another coup of the government without bloodshed as in 1932. I could not have arrived in the country at a more exciting time.

The first week I started my work of purchasing books at the different book shops. Most of the shops are no more than holes in the wall but surprising enough they did have books which we need in the library. The letter of credit worked out very well and Mr. Gibbons, the disbursing officer of the American Embassy, was most cooperative with reference to granting funds to me for the purchases in connection with that credential.

I quickly cleared out books which I was able to locate in English, German, and French. Among these are books which deal with the Siamese language Siamese-French-English dictionary by Pallegoix and Vey, Deutsch-Siamesisches worterbuch by Jumsai and a four volume work by a Siamese entitled EnglishThai dictionary.

One of the first steps I took was to buy copies of the Bangkok telephone directory and the Siam directory for 1247. 
Both of these books had a mine of suggestions as to places where publications would be available as well as the names of government officials whom I planned to see with reference to international exchange. Other valuable handbooks secured through the Department of Commerce included the past four issues of the Commercial directory of Siam and the latest issue of the Statistical yearbook of Siam - both of which are bi-lingual in content.

For the purpose of securing books in Siamese, I arranged with the Department of Publicity to have the Chief Liaison Officer in the Foreign Division to go with me to the various book centers. He has been an exceedingly valuable person with his intimate knowledge of tire book trade in Bangkok. He has taken a number of courses in law at the University of Moral and Political Sciences and Chulalongkorn University and as a result took me into a number of these small shops where we dug out valuable documents and legal treatises. The books were loaded into the jeep and off we proceeded to the next place. Among the law materials acquired I was fortunate enough to locate a complete set of the Slamese Laws and Enactments consisting of 58 large volumes; also, a trip out to the National Assembly made possible the securing of a complete set of the Parliamentary debates, which fills three good size boxes. Among the books procured from the commercial press, the subjects of Siamese literature, history, drama, art, archaeology and religion were strongly represented. I was disappointed to find very few volumes on economics, trade and agriculture. At one music store I secured some music books and a few scores of Siamese music composed by Siamese.

The International Translation Company in Bangkok makes it possible to secure in English the Government Gazette, the Navigation laws, the Revenue code and other documents which appear to me to be indispensible to American business firms interested in Siam. Arrangements have been made with this company to inform us of new translations whtch they publish.

Arrangements have been made with the American Embassy here to send to the Library their daily sheet of translated extracts from the local Siamese newspapers. Unfortunately they cannot supply us with many back issues.

Due to the fact that the State Department has not recognized the new Siamese Government, I was not able to go too far with reference to the exchange of official publications by the two governments. I merely laid the groundwork for conferences and everything had to be on an informal basis. Through the courtesy of Ambassador Stanton I have secured from the Embassy file copies of the significant correspondence in connection with the exchange of publications agreement established on last September 5th. 
A copy of the new Constitution proclaimed at the time I was in Bangkok was secured in both Siamese and English.

Arrangements were eoncluded with one bookdealer to act as our agent in Siam for the future procurement of books published in Siam. This company will also see to it that we are furnished with fresh information concerning all serial publications and will take the responsibility of handling our orders for the ones we desire. The name of the establishment is Nibondh, located on New Road, Sikak Phys Sri, in Bangkok; the manager's name is Sunetra Kongsiri. Upon my return to nmerica I am to establish their credit account in some Washington Bank as they now have in London. This will facilitate matiers when the Library makes payments for services rendered us by this dealer.

A complete list of newspapers and periodicals published in Bangkok in English, Siamese and Chinese was compiled. After arefully selecting the best of these serialy, orders were placed for them through the above mentiond dealer. Every effort was made to secure back issues of these newspapers and serials but not with too much success. I have explained to the dealer the Library's policy about continuation orders for serials.

Mr. Teg C. Grondahl, the Public Affairs Officer and Miss Dorothy Ward, the U S I S Librarian, were helpful with their ready information concerning the many government ministries and departments, location of official offices, educational and cultural institutions within Bangkok. They, along with Mr. Roach of the Embassy, made transportation possible for most of my official business. I am thoroughly convinced of the value of having an Information Service in foreign countries; and when it comes to the Library with a highly selected collection of United States pericdicals and nowspapers, standard reference works as well as the best of the latest books from America, it is utterly impossible to calculate the steady influence exerted in the formation of international goodwill and cultural interchange.

While in Bangkok, I sew the National Library a number of times for it is located in a prominent place on one side of the royal plaza not very far from the grand palace. The National Library of Siam is less then half a century old. It was founded in the year 1905 by the amalgamation of several amaller state libraries into one centrilized library. At first the library collections were housed in the grand palace of the Siamese kings, but by 1917, when the collection of books had grown to the size to demand larger quarters, tho library was transferred to its present building. In 1926 the Royal Institute of Literature, Archaeology and Fine Arts was established by royal decree and since that time the National Library has been a section of the institute. 
The Library is divided into two distinct departments; namely, the Department of Printed Books, which is officially called the Vajiravudh iibrary in memory of King Rama VI or Maha Vajiravudh, whose collection of books became an integral part of the Library; and the Department of Manuscripts which is called the Vajirayan Library in memory of King Nongkut's name when he was in the Siamese priesthood prior to his accession to the throne. The Department of Books is divided into two sections: Siamese and Foreign. Within this Department are included maps of every description.

Within the Department of Manuscripts is a collection of Cambodian manuscripts which, I would hazard the guess, is the richest in the world. One of the chief objects of interest to be seen in the library is the magnificent lacquer and gilt cases in which these manuscripts are kept. Likewise this Library has an unrivalled collection of Siamese manuscripts. fs would be supposed, since Siam ise a Buddhist country, a large number of these manuscripts are Buddhist prayer books and religious works. Dus to the fact that the more ancient mamscripts were destroyed when the Burmese invaded Siam and completely annihilated the capital of Ayudhya in 1767; the majority of the manuscripts date back only as far as the latter part of the 18th century. On more than one occrsion I was told of this wanton destruction at the hands of their western neighbors, the Burmese.

I was interested to note a custom which aids in the spread of knowledge. Since the turn of the present century it has been the custom that relatives of a deceased person distribute books as souvenirs to friends who come in attendance at the cremation ceremonies. While many of the books distributed are purely religious, historical and literary works are being published in greater numbers. By this method a knowledge of many unknown and significant works have been spread among the people. Application is made to the National Library by those who desire to publish such works and the council then selects a suitable work from among the unpublished manuscripts.

Theoretically the public has free access to the books within the Library ut since all books are le pt under lock and key it is not easy to browse through books as is the custom in American libraries. Newspapers and magazines are kept on the tables in one room and are therefore used much more than the books. Also, there was no card system which we employ in America. The circulation of books is extremely low, for very few people are ever seen at the library at one time. I am convinced that new methods and a program of publicity would call to the attention of the Siamese people the valuable materials which they have stored in their national library. 
is the Damrong Collection. This collection consists of the books owned and used extensively by the late Prince Damrong (1862-1943), son of $\mathrm{H}$. M. King Mongkut. During the long course of many years of outstanding and important service to his country in various departments of the government he collected hundreds of books on all subjects. The collection includes many books in English and of course his own Siamese language. The books are now housed in a smill building located just to the rear of the national library, and is referred to as the Damrong Room. The structure was built during 1947 and the inauguration took place on Prince Damronges birthday anniversary, June 21, 1947, at which time the books and the other personal property of the Prince ceased to belong to Princess Poon, his daughter, and becime national oroperty under the auspices of the national library. A complete list of the books in the DamrongeCollection has been compiled during the pest two years. Arrangements were made with Princess Poon so that I might take this large catalog back to Washington with a view to checking it against our Sinmese Collection in the library and thus determining the material which might be microfilmed for the Library of Congress.

During one of my visits to the National Library of Siam, I had an interesting conference with Phya Anuman, the Director of the Fine Arts Department and Head of the National Library. This Siamese gentleman is non-political in interest, has done considerable research work and has published some books in Siamese, and is the person responsible for Government publications and exchange relations with other governments. It was he who arranged for the shipment of Siamese books which we received last year at the Library. Prior to the personally conducted tour we had an interesting conference. Three facts came out of our talk together: (1) For some reason it seems that the shipment of Government publications which we had sent to the National Library of Siam had been delayed. I assured him at the time that I would look into the matter upon my return. In the meantime, however, the matter was investigated and the U. S. publications were sent to Siam not many months ago. He was also pleased that arrangements had been completed between the Governments of Siam and the United States whereby they will receive respectively all important government publications on an orderly basis. (2) He informed me that only material dealing with the arts and sciences will be deposited in their National Library. (3) All other materials sent by the U. S. Government will be distributed to the respective ministries rather than stored in the National Library.

Arrangements were made with Mom Chao Rajadabhisek Sonahul, the Rector of Chulalongkorn University, and Rong Syamananda, the Secretary-General and Acting Librarian of the University, whereby exchange relations were opened between tie University and the Library of Congress. During a visit to the University Library I saw certain volumes which had come to the institution from the American Book Center. 
The Viet Nam: News Service at 543 Silom Road in Bangkok, is an important center where publications dealing with Viet Nam may be secured. Through special exchange arrangements with Mr. Le Hi, Acting President of the Viet Nam Government Delegation, and whose office is at the Viet Nam News Service, the library of Congress is to receive semi-monthly by air mail the Information Bulletin issued by the Service. Two Years Achievement of the Viet Nam Nationalist Government and Viet $\mathrm{Nam}_{2}$ a New Stage in her History, two monographs, were secured along with a file of the Bulletin issued in 1947 and 1948. While at these headquarterse I noticed anong the many slogins and posters on the walls these words: "We are resolved to devote all our spirit, all our strength, our lives and our wealth to preserve steadfastly our national freedom."

Exchange reletions with the Siam Society which the Library enjoyed before the war has be en resumed and the Society's Journal and Natural History Bulletin are now being received.

There was considerable difficulty in securing maps from the Siamese Government. The reason for this is the fact that the Maps Division was under the Ministry of Defense, which is rather an important part of the Government following the coup dietat of last November. When we arrived at the gates, guards were present everywhere and we had to secure special permission to enter the outer gates. I found my way to the place where the maps were kept. After the authorities had pondered about 30 minutes over my request, I was told that a written request would have to be made through their Dopartment of Publicity before any maps could be issued and then only on a selected basis. The written request was sent and upon my return to Brngkok in late March, I followed up the matter of securing the Siamese maps from the Royal Survey Department of the Army. In response to no request Major General Phra Vibhati, the Director of the Survey, presented the Library of Congress with the maps issued by the Survey Department. Attached to the official letter, confirming the presentation, was a list of the maps being sent through the American Embassy at Bangkok.

Considerable information concerning the organized bar, legal publications and other questions of interest to the Law Library were secured. The University of Moral and Political Sciences has a printing establishment which was able to furnish scores of books with special interest to one concerned with Siamese law. Among the publications received were the printed lectures of the professors in the Political Science Department of the University. This press also issues the Iaw Journal of Siam.

Through the courtesy of Dr. Bunliang Tamthai, whom I met on the plane en route to Bangkok, I was able to see Dr. Chalers Prommas, Rector of the University of Medical Sciences, Sirriraj Haspital. Dr. Prommas gave me information concerning the Medical 
Mssocintion of Siam and the Joumal published by that Society. An arreement wes riade ri.th the Rector of this University for the exchinge of this Journal and other publications for certain Libr-ry of Confress oublications.

I visited the Brnkok Post whero I met the editor, an American by the name of llexander lacdonald, who has been sending the paper to the wibrary on a complimenting subscription basis. Since 1 considered the Post to be the lending En ilish newspaper in Bangkok, I arcanjed with the Americen Pribessy to nave it sent to the Library by air.

The amount spent in Siam for lesal and peneral matcrial amounted to a.bout 19,000 beht or 950.00 . 


\section{BURINA}

I left ljangkok on Sunday corning, Deceniber 7, by BOAC and arrived in $3+n$ Toon in a little over two hours. The trio ves uneventrul vith the excention of the time when ve ncarcd Rangoon thei could sce that Mr. torn city from the air. lo fley loir en ou to sec with consicerablo detoil the destruction done by bombs and firc. The vicw of tac Shwe Dacon was magnificient and fortunately this fomous Buddhist shrine hed not been touched by the var. It was a cloar doy and. I could pick out readily old landmarks with inich I was familiar;

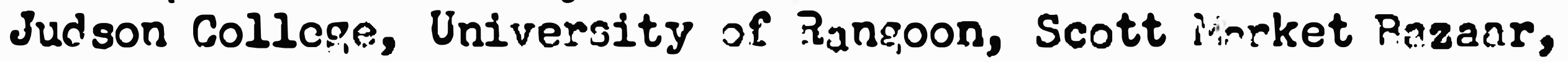
the Secretarint and other noints. Rangoon was entircly difforent from the eity which I knew seven years 250 . Mlready $\rightarrow$ number of buildings have been cithcr reconstructed or redecoratcd and I ail told that considerable improvement has becn made this past year. In most cases mere buildines merc bombed the rubble has been cleaned up, and in these open spaces hundreds upon hundrcds of bamboo-thatch roofed houses have been erected for dwelling places. Rangoon was ncver a clean city when gauged by wcstcrn stindarcis but it is filthy now; tise streets are dirty, the severs are spen and peoole ere living in most conjested conditions. Houses of these kinds are the only plinces where thousands of people have to live, havine lost during the wer their hous:s and all they had. There are no strcet caro and the common form of trinsijortation were reconditioned army trucks made into buses; jeens were seen overywhere as private cars. They were sold cheaply by the Army as surplustand many ncople have then who otherrise would have no car at all.

For the purpose of starting the rircininery in connction with the exchenge of publications between the two Governments, tio first day I went to the Sccrctnriat to sce $U$ tin Tut, the Forel n linister, $U$ Tha Din, his denuty, and r. I oses Ezekiel in the educetional department, who seemed to be the rien tirrourh whom all such matters must s.0. $\Lambda 11$ wore receptive to the gencral idea and were cle nsed that such an exchinge could bo rade at the minimum expense. They cilled my attcntion to the fact that the Burma Government had been interested in securing, a number of U.S. Government nublicetions for various denartments of thelr Governinent. Upon the return to the Nmericnn Embassy, I t ook over a large folder of memorenda which the Embnssy had received from the Burma Government requesting certain U.S. Government publicntions. These requests will be correlated and granted in conjunction with the exch-nge of public tions. Before lenving langoon I laid the 
necots-ry ground work wiscreby the exchange of official matorials might bc carried out with the Government of Burme. Fur thermore, final arranzements kere nade rith 4 laung Hla, Suporintendent of the Governrient Book Depot, end his assistant, U IKin Naung, for the offici-1 Burma materials which the Libriry of Congress docs not posscss. I also presented the finel drofts of the agrecuent notes to ir. Robert 'cly, Charge d'affeirs of our Embnssy, who in turn transmitted thom to $U$ Tin Tut. The agreerient came into effect on ipril 5, 1948.

Upon arriving in $R$ angoon, I vas told by many people that I rouid not be able to find much in that city, but vithin a few weeks it wis discovored that there wore many books in the extremely small, onc-room bookstalls. Jiy intimate knorledge of Burmese made the rork in Burma much easicr and certainly more intcresting: both in buying at the bookstorcs as well as meeting, Government offlcials. I combed the city and was satisfied with whet I secured for the Library's Burmese collection. Hovever, there was not an abundence of postwar publications since there are far less printing establishments than before tho war. Priccs were terribly high. $\Lambda$ book which had listed on the covor its prerrar price of eipht annas would be sold at four times that price or two mupees.

Mr. Locket, the manager of the Iducational Iookstore in Rongoon, vill be the Library's asent for publicitions ivithin Burma. The ir atter of what the Library ras interested in receiving, including, norspapers and journols, was presented in detail and he has consented to take this responsibility.

A specinl effort wos made to secure the best Buddhist literature which ind been published in that strong Fudihist country. Two sets which nave been on the Librery's mant list for many years finally have been secured; namely, (2) the Burmesc text series published by the Burma Rescarch Society and edited by $U$ Pe liaung Tin, and (2) the Ton Buddhist Birth Stories of the Buddha. Three publithing houses in Rangoon which publish almost exclusively Buddhist material supplied the most significant books published prior to and since the war.

With Burma recently having bccome an indopendent notion, the acquistion of publications dealing with the current political trends was important. Chief among these vere the following: The Ner Burma in the New lorld. The Presidential Address Delivered by Mafor Genaral hune San, iray 10, 1940, A.F.P.F.L. Convention Brochure (1947), and The Constitution of the Union of Burms (Burmese and inrilish editions).

A complete list of the Buma newspapers ras compllod and at that time I listed 35 papers being published in Bumese, English and other languares of the country. Subscriptions were placed for five of the leading dailics, two of which-alen Times of Burms and The Bumen $\ldots$ aro to bo sent to the Library by tho weckly alr pouch of the Embrssy in Rangoon. Finding 
it Impossible to secure back copies of any Burme newspapers at the respective publishing plants, I approached the American Embassy about passine on their back issues to the Library of Congress. To this they agreed and provided me with back copies for 1947 of the following newspapers: New Times of Burma, The Burman, Burmese Review, Rangoon Mirror, Monday Monitor, Burma Tribune and the Voice of Burma. The files of the New Times of Burma and The Burman were not complete but lacked. very few issues. The Embassy had not back files of the papers in Burmese. Arrangements were completed with the American Embassy to have the weekly summary reports of the Burmese press sent to the Library of Congress by air. The monthly reports are far more extensive than the weekly reports, carrying considerable interpretation of events and trends, and are not available to the Library since they are classified as confidential. It appears to me that arrangements ought to be made with the State Iepartment at Washington to permit a copy of these monthly reports to come to the Library.

Apart from the newspapers subscribed to, there are no serial publications to which the Library might subscribe. $\mathrm{U}$ Pe Maung Tin, a retired professor of the University of Rangoon, informed me that the Journal of the Burma Research Society has not been reissued since the war but ought to be coming out within 1948. He also stated that no new volumes have been issued in the Text Publication Series.

The movement of commanism finds definite expression in Burma. To receive a good picture of what the communists are doing, there is no one book to which a person might turn. The daily press is about the only source of information at the present time. The Comnunists are are organized and have representatives in many villages; their literature is sold or distributed regularly on most trains and in towns and cities.

Through the courtesy of a friend of mine, U Nyo Mya, I met with a group of the leading Pongyis, including the president and secretary of the MII-Burma Buddhist Pongyls issociation at which time was discussed the matter of that society's supplying the Library of Congress a collection of Buddhist books. As a result a special campaign is to be launched to secure books and manuscripts from various monastic libraries from al] over the country.

The amount of legal reference books secured was much less than that acquired in Siam. I was fortunate, however, when buying a portion of a library of a former lawyer friend of mine, who died a few years ago, to secure 
A Selection of Leading Cases on Buddhist Law with Dissertations by U May Oung (2nd ed.), Principles of Modern Burmese Buddhist Law byes. C. Lahiri, A Decennial Digest of Burma Rulings, 1923-32 by C. K. Tambe and a Digest of the Civil Cases ofeBurma......

An interview with Taw Kyone Boon, the Secretary of the Rangoon Bar Library Association, provided me with considerable information and material concerning the organized bar in Burma. Chief among this information was a list of the members of the Rangoon Bar Library ssociation in the high court consisting of 98 names; also a list of the Committee Members of the Rangoon Bar Library Association, consisting of 10 names. He explained that lawyers were divided into three classes in Burma: (I) fdvocates who can appear either in the high court at Rangoon or any district court or subdivisional court; (2) Hirher grade pleaders who may appear in district courts or subdivisional courts but not the high court; and (3) Lower grade pleaders who entertain the same privileges as the higher grade pleaders but in general do not have as high professional standing. In langoon only advocates are eligible for membership in the Rangoon Bar Library Association; while both grades of pleaders in Rangoon have their Rangoon Ba: Association. The Bar Council is a statutory body founded under the Bar Counciles 1 ct passed in..... Prior to the war there was the legal publication called The Burma Law TImes; at present there is no publication by the bar. One of the leading professors of Law at the University of Rengoon is Dr. U Ba Han, who is also a committee member of the Rangoon Bar Library Association. Unfortunately I was unable to meet him while in Rangoon. Taw Kyone Boon stated that the Law Library of the high court is adly, dopleted since most of the books were destroyed during the war. There is no list available now. All court decisions are published in the Rangoon Law Reports which are published by the Government Book Depot. All laws and enactments appear in the Burma Gazette. A chronological set of Burma Laws are to be found in the Burma Code, which is also an official publication. He also called my attention to a book published at the Government Book Depot entitled Rules for the Admission of Advocates and Pleaders in Burma. Arrangements have been made for the Government to send (this book) to the Library in the materials to be sent on exchange. Taw Kyone Boon will be a valuable person in connection with future relations with the Library of Congress and he has assured me he will keep me informed of any developments on legal publications and trends in Burma.

At a gathering given by Ambassador Stanton of Bangkok who was President Truman's representative at the Independence Celebration in Burma, I met $U$ Thein Maung of the High Court in Burma. During the course of our conversation he verified the information about the Bar Association which Taw Kyone Boon 
had given me a few days ago. He further related the fact that. up to recently all the court proceedings were in English. From now on it has been decided that all proceedings are to be in Burmete as the official language with English as a permitted altornative. All evidence given in Burmese will be recorded in Bursese without translation. $\Lambda l l$ evidence given in any other language will be translated if possible into Burmeset $\Lambda l l$ court proceedings will be printed in Burmese. Within a year from now he expects to see all acts, ordinances, government documents and official publications published in Burmese. Speaking as a recently retired member of the University Council, he said that the curriculum at the University of Rangoon will be given in Burmete as far as it is possible and as soon as possiblet History and literature course are being given in Burmese at the present time. Science courses will have to wait until technical terms are translated into Burmese. In answer to certain questions I asked about the need for better Burmese dictionaries he said that the Burmese-Burmese dictionary being compiled by Dr. $\mathrm{U} \mathrm{Ba} \mathrm{H}$ an and others is proceeding slowly. He further related the fact that a Burmese-English dictionary is now being prepared in England under the editorship of J.n. Stewart. The work apparently is to be an exhaustive work since it is being printed part by part as they are ready. He thought that possibly copies of the parts already printed could be secured from U Htin nung, President of the Universitg.

Another important conference with a Burman le ader was with $U$ Pe Maung Tin, whom I knew formerly as a professor of the University of Rangoon but now is a professor at the recently organized National College. From the time I arrived to the time I left his house about an hour later, the conversation was in Burmeset I point this out primarily to show the new trend among the Burmese leaders in desiring to speak with westerners in their own language, whereas before the war English wat the order of the day. We talked about the Burma Research Societ,y, the Text Publication Series, new Burmese dictionaries being compiled and the Library of Congresst He also related the important fact that the Government had authorized a Burma Translation Society with about 10 Lakhs at its disnosal for the purpose of translating into Burmese those books of the west which tiey look upon as important. He told me the University Library had suffered a great loss from the war, a large portion of the collection having been destroyed by fire. Also, to augment what little the University had a present, the Bernand Free Library had been moved out to the univorstty.

One afternoon I witnetsed the signing of an educational exchange agreement between Burma and the United States whereby an American Educational Foundation in Burma was established and will-operate under the Fulbright Act. According to the 
agreement students from Burma will be aided while attending schools in lmorlos and studant srom krerles will be alded while attending schools of higher learning in Burma. It is also expected that the Foundation will provide American guest professors for the University of Rangoon, as well as the translation of American te tbooks into Burmesee

A conference with Major Thackwell, the Director of Survey, revealed that a good number of maps dealing with Burma and the Shan States are still availablo. He assured me that when the exchange agreement is made he would gladly cooperate to furnish the Library with those maps which we desire for our collection. One important map wich is available through his office is a large wall map of Rangoon.

U Htin Nung, the Presicient of the University of Rangoon, was especially interested in the Cumulative Catalog of Library of Congress Cards as well as in the whole idea of the microfilming process. At present the only publication the University can supply on exchange is the University Catalog.

The Government of Burma, at least certain officials within the government, is aware of the fact that Burma does need a national library. No definite action has been taken so far and with the exception of a small group of interested ones, there have been no committee meetings to consider the whole matter of a national library. When told that the Library of Congress would be ready to assist in any way that it could, Mr. Ezekiel and U Tin Tut seemed grateful. Special interest was shown in the Cumulative Catalog of Library of Congress Cards.

At the request of the President of the Burma Journalists Association I delivered a talk--in Burmese and English--at the Headquarters of the B.J.A. in which I told them about the Library of Congress and its various functions to those who seek its services.

In all, there were about twelve boxes of materials to be shipped from Rangoon. 'Arrangements were made with Mr. Acly and Mr. Holloway to ship then to the Library by a number of sea pouches which they had on hand. Of the total number of volumes purchased in Burma I would say that about 85\% were in Burmese. The total amount spent came to Rs. 1940-11 or roughly \$600. Compared to the expenditures in Siam, there was a very small amount spent for legal materials: Rs 120 or about \$3e. 


\section{MAIAYA}

Upon leaving the country of Burma, I proceeded to Singapore and the Federation of Malaya - the latter belng a newly formed 8 tate as of February 1, 1948. It was in S1ngapore that I secured important historlcal materlal through the fortunate acquisition of certain newspaper flles.

The trip from Rangoon by BOAC was interesting to me since I had never seen the Mergul Arch1pelago of $f$ the Tenasserim coast of Lover Burma. To be able to see them from the a1r 1mproved the view, for one was able to observe the contour of the topography and the extremely rough coastline of certain lolands as they jutted out of the Bay of Bengal l1ke large, sharp, Jagged 1cebergs. V1ews like these made the hobby of color photography most 1nteresting.

A few days after my arrival the Stralts Times carrled a notification of my visit in Singapore for the Library of Congress. The accounty appearing on the front pagey was captloned "Wastepaper Man-with a Difference" and emphasized the fact that I was Interested in securing newspapers published during and just after the war, "whlch many would regard as so much waste." Undesirable as the lead may have appeared, it brought good results. Letters and phone calls were recelved from those who had materials for sale; others brought books to the hotel for 1nspectlon. Chlef among these were offers to sell a certain paper called the Svonan Shlmbun, the only English newspaper published by the Japanese during their occupation of Singapore. Beginning publication on February 20, 1942 and extending to september 4, 1945, the complete flle cons1sts of over 1000 18sues. In my short time there, three offers were made: one wanting 10,000 Stra1t: Dollars (US $\$ 5,000) y$ another $S \$ 34000$ and a th1rd $S \$ 1,000$. All were informed that the L1brary was interested in buying the paper, but I assured them that the flle was not belng bought for future speculation but w1 th the sole purpose of placing it in our National Library for research students who w1li. want information concerning the war in th1s part of Southeast Asia. The complete f1le of the Svonan Sh1mbun was finally bought for $\$ \$ 700$ (US $\$ 350$ ) from the person who made the third offer.

Anxlous to have information concerning the events immedlately following the Japanese occupation, I Epproached the management of the Stralts T1mes and the S Sngapore Free Press about the matter. In the course of my ingliry I was able to secure as complete a flle as possible of these three papers-the Stralts TImes, the Sunday TImes and the S1ngapore Free Press-from the tIme of the liberation of Singapore in September 1945 to January 1948. Th1s flle of postwar papers cons1sts of well over 1480018 sues in all. The Svonan Sh1mbun ceased publication on September 4, 1945 and the Stra1ts Times, w1th the permission of the Brit1sh military authorit1es, began publication only three days later. Although the printed price for back coples was ordinarily high, the prioe which the management asked for the P1le was reduoed considerably alnce the purchase was for the national library. 
The editor of the Straits T1mes, Mr. A. T. Simmons, plans to complie a rellable directory of S1ngapore and Malaya in the course of this year or by the f1rst of 1949. Furthermore, in e1ther 1948 or 1949 a Stra1ts T1mes Annual w1ll be 18sued s1m1lar to the elaborate one produced in 1939 just prior to the war. The management was also considerate in providing the Library with a copy of this 1939 Annual which has been long out of print.

While in Penang, Mr. Soon Chang Hor, Publlc Relations Offlcer, as818ted me in making connection with the papers for wh1ch subscriptions were placed. These 1ncluded the Ecoriom10 Melayu, Sulah Kemajuan and Dunia Babaru In Malay and the Stra1ts Echo and the Sunday Gazette in Engl1sh.

After spending conslderable tlme at Kelly and Walsh, the largest bookstore in S1ngapore, 1t was possible to secure almost all the latest materials published currently in singapore and Malaya as well as a few 1 tems whlch I had on my Malaya want $118 t$. The prices were high but nothing like they were in Rangoon. I found the manager, Mr. Dav1s, to be a person who not only knows publication sources, but also 18 keenly interested in aiding Ilbrarles. As a result this 11 rm was engaged to be the library of Congres' agent in Malaya and Singapore.

Within the past two years there have been a number of new publiciations in singapore but not as many as publishers would have produced $1 f$ paper had been easier to secure and labor costs had not been 80 high. Th1s was emphasized by Mr. Reed, the Managing Director of the Malaya Publishing Housey who sald they have enough books to be printed to keep them busy for the next 11ve years. It 18 th1s $11 \mathrm{rm}$ which publishes a large number of the textbooks used in the Malayan schools, many beling books 18sued by the Department of Education. While in Kelly and Walsh, Mr. Dav1s showed me a whole shelf of books, long out of print, which they will republish as soon as time permits.

Among the books purchased, I felt fortunate to locate the Acts and Ordinances of the Leglslative Counc1l of the Straits Settlements from lst Aprilulo67 to 7 March 1898 , two volumes, which the Ilbrary has hoped to have mlcrofllmed for the past two years through the Publ1c Records Offlce in London. Another old book I had hoped to find in Burma was in Singapore: Burmah, 1 ts people and natural production ... by Franc1s Mason, pubIlohed in Rangoon in I860. That was a find for only $\$ 10$.

The following new publications purchased w1ll be of interest to those desiring information on Malaya:

The People's Constitution for Malava. Commerclal Directory of Malnva. 1947. Malaya Upalde Down by ChIn Kee Onn (1946). The uGood Cit1zens Gulde (published durlng the Japanese occupation)

Malayan Problems from a Chinese Point of V1ew by Tan Cheng Look. 
Facts about Sarawak.

Manual of Rubber Planting, Minaya by A. T. Edgar.

Malaya also proved frultful with reference to legal materlal and Information. Mr. B, A. Mallal, editor of the Malayan Law Journaly was pleased to place the iltrary of Congrefsi on his exchange 118t of publications. Back copies in 1946 and 1947 were kindly supplied. While there I was able to sezure the important law books: Mallal's Digest of Majayan Case Tair a Cinzrekf.ns1ve

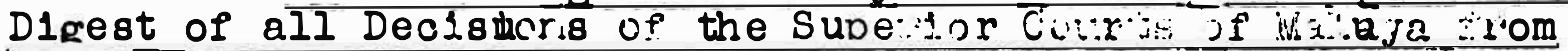

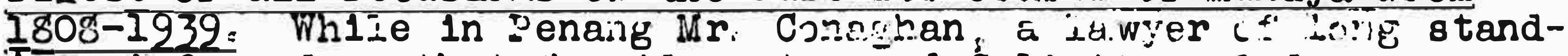
Ing, Informed me that the Advocates and Solicltors ordiyance, 1247. provides complete information regarding the Bar in Maiaya and regulations for practicing lawyers. Ihis Ordinance (a supplement to the Malayan Union Gazette, February 17, 1947, no. 5 , vol. II, notification no, 1024) and a complete list of the Advocates of the Supreme Court were secured fillom the Reglstrar of the Supreme Court at Kuala Lumpur.

A number of conferences w1 th Mr. Geirge Thomson, the Public Relations Offlcer for the Colony of Singapore, and Mr. Vine and Mr. Taylor of the Government Printing of fice, made 1t possible to lay the ground-work for the exchange of offlclal publications. Significant among the materlals selected are the following legal publications:

Chronological Table of Stralts Settlements Laws (annual)u Manual of the Laiw of Extradition and Fugltive Offenders... Munlclpal Ordinances of the Straits Settlements Index to Munic1pal Ordinancer Jrders. Rules. Requlations and Bv-laws (annualu Stra1ts Settlements Law Reports (annualu Handbook for Public Prosecutors in Malaya Ordinances Passed During the Yeärs, 1941. 1246. 1947, (bound volumes)

Bes1des supplying the Government Gazette from April 1946-the date when 1t resumed publication--to the present, they w1ll also supply us with the Gazette from the years 1880 through 1900, wh1ch w1ll f1ll a large gap the L1brary has had for some yearsu

While therey they showed me a copy of the book whlch the Government of Singapoure presented to Princess Ellzabeth on the occasion of her wedding. It was entitled A Presentation Book of Prayers Offered by the Varlous Communities of Singapore on the Occasion of the Wedding of H.R.H. Princess Ellzabeth.

At Kuala Lumpur, the Capltal of the new Federation of Malaya, arrangements were made w1th Mr. McHugh, the Director of Publlo Relations, Mr. Hammet, the Deputy Chlef Secretary and $\mathrm{Mr}$. Holland, Superintendent of the Government Printingy for the exchange of offlcial documents 1ssued by the Federation. Among the latest publications 1ssued by the Government Press there were a number dealing with the matter of the new Malayan Const1tution: 
Summary of Const1tutional Proposals for Malaya... ( 1946) Constitutional Proposals for IValaya... (1946)

Summary of Revised Const1 tut1onal Proposals ... (1947)

Statements of Poll cy on the Future Const1tution (1947)

Ihe People 8 Constitution for Malaya

When conferring with Mr. Hclland, our discussion brought out the 1mportant fact that the Government Press does not print all the publlcations of all Government Departments due largely to the lack of fac1lit1es. It was therefore concluded that three steps ought to be taken: (1) For me to 1nd1cate on the Government Press $118 \mathrm{t}$ the materials the Llbrary wants; (2) For Mr. McHugh's offlce to complle a l1st of all Government publications 188ued by Government offlces not now printed by the Government Press (th1s $118 \mathrm{t}$ was complled and recelved while enroute a couple of months later); and (3) for these publications to be sent to Mr. Holland who will assemble, pack and shlp the $8_{2}$ me to the Llbrary of Congress. Ur. Holland stated that he would do h1s best to secure back coples of the Br1t1sh M1l1tary Adminlstration Gazette.

The offlce of Mr. Mchugh produces a number of publications whlch he made avallable to the Llbrary. Chlef among these was a Sem1-monhtly Digest of Engl1ah, Malay, Chinese and Tam1l newspapers, pubilshod or CIrculating In the Malayan UnIon. Most all the publications prepared here are 18sued in four languages: Engl1sh, Ch1nese, Malay (Jaw1) and Tam1l. Th1s pract1ce 18 qu1te different from the other Government offlces which prepare the $1 \mathrm{r}$ publications in only English. A monthly publication called Malayan P1ctorlal Observer 18 distributed widely for English readers; Chermin Melayn $I_{B}$ a Malay paper publ1shed fortnightly and distributed malniy in rural areas; Varthaman1 18 a fortnightly Tamil paper distributed malnly on rubber estates.

Mr. P.uH. Bonnet, Surveyor-General for the Federation of Malaya, indicated that he would be able to sond to the Library of Congress all new maps 1s8ued in 1947 and 1948 as a part of the exchange agreement between the two Governments. He will provide me with a revised l1st of all maps whlch have been published and those to be printed during the coming year.

The Rubber Research Inst1tute of Malaya 18 located some d1stance out from Kuala Lumpur. In talking with Mrs. W. S. C. Re1s and Mr. C. E.UT. Manny the Inst1 tu te w1ll be pleased to establ1sh exchange relations with the L1brary on the basis that they already recelve a number of publioations from the $U$. $S$. Government - 1.e.y Department of Agrlculture and Smithsonian Institution. They would desire any library publications which would be of a special interest to thelr kind of Institute. Also, they would appreclate (I) any publications of the Department of Commerce dealing with rubber; and (2) a 118t of publications dealing with synthet1c rubber, chemistry of rubber or cultivation of rubber. The Institute supplied mo with all their publications whlch wore avallable. 
A conference w1th Dr. R. Lewthwalte, Director of the Inst1 tute for Medical Research, Malaya, revealed that the war h1t the Inst1tute badly: looting having left the laboratorles stripped of modern equipment and the library of many volumes. It would be appreclated if the Ilbrary were 1n a position to supply the 1ndex volume of the Encyclopedla Britannica, 14th edition, to replace one which was stolen. The DIrector provided me w1th h1s latest annual report and the latest of a long serles of a Bulletin which includes a list of those papers 1ssued by the Institute. Upon request, any of the desired Bullet1ns will be furnished.

Ilikewlse, exchange arrangements were made with the South Seas Soclety whereby we w1ll secure the1r quarterly Journal, the monthly Nanyang M1scellany pamphlets wh1ch m1ght be 18sued during the year and a set of clippings which they take from many newspapers of Southeast Asla. These publications are mainly in Ch1neso with brief sections in English.

Exchange relations were also established with the Indoneslan 0ff1ce in S1ngapore wh1ch w1ll send the Ilbrary 1 ts da1ly Indoneslan News Service 1soued in bo th English and Malay.

The L1brary w1ll also recelve on an exchange bas1s the following ser1als: Journal of the Malayan Nature Soclety, 1ssued by the soclety; the Malayan Eacator the offlclal organ of the Malayan Teachers' UnIon; the Malayan Agrlcultural Journal 1 soued by the Government at Kualn Lumpur; The Planter, organ of the Planters' Union of Malaya; and the Medical Journal of Malaya. offlclal organ of the Malaya Branch of the Brit1 sh Medical A880clation. Mr. C. F. Young, publisher of this Medical Journal, has supplied the Llbrary with the back numbers of the Joumal dating from September 1946, Vol. I, no. I.

Exchange arrangements were reopened w1th Mr. H. D. Collings, the head of the Raffles Museum and the editor of the Museum Joumal. Th1s publication, not having a regular t1me of appear ance, Is printed whenever the material is sufficient enough to warrant a printing. There is usually one 188ue per year. The last one published was no. 16 wh1ch came out in late 1947. All past $18 s u e s$ of the Journal whlch are desired will be furnished In exchange for all past Issues of the Llbrary's Journal.

Housed in the same bullding are the offlces of the Malayan Branch of the Royal Aslat1c Soclety with Dr. C. A. Gibson-H1ll as the Secretary of the Sooloty. Both of these men were taken w1th the idea of the avallablilty of microfilm copy from the Library as well as the Llbrary of Congress oards whlah they might seoure for thelr respect1ve catalogs. The Joumal of the MBRAS has been recelved for many years by the Llbrary, and the last two 1s8ue of the Journal whlch have come out since the war have already been sent to the Library of Congress. S1nce the holdings of the Soclety in Singapore are deposited in the Raffles sureum and Llbrary, he felt there was no need for the Ilbrary to send 
another set of the Library of Congress Journal and other Llbrary of Congress publications over and above what 18 being sent to the Raffles Llbrary and Museum. Dr. G1bson-H1ll sald that if there were any gaps in our holdings of the JMBRAs, he would gladly supply the m1ssing ones, although the Japanese did clear out certain lssues, partioulnriy those dealing with language. He also polnted out that not all volumes carry four parts, sometimes there belng only two or three parts in one year. He 1ndlcated that we may not have recelved Vol. 19, parts 2 and 3 (1941) wh1ch was sent just prior to the outbreak of the Paolf1o War. Th1s fact of 1rregular 1ssue of these publications 18 an important one when 1 comes to collating such materlal.

I had a conference with the Arohivist of the Raffles Llbrary and Museum, Mr. Tan Soo Chye, a graduate of Raffles College. It is in his offlce that all applioatlons for reg1stration of all publications in Singapore have to be submitted. From these applications are made the 118ts of reglstered books whlch are then printed quarterly in the Offlclal Gazette. By law, publication has to be reglstered within 30 days after the date of publication. Th1s registration at S1ngapore used to apply to all the Stralts Settlements--1.e. Singapore, Penang, Wellesley and Malaooa--but now Includes only publications appearing within the Colony of Singapore; publications in these other ment1oned places are now reglstered at Kuala Lumpur. In order that information ooncerning now publications might be seoured as soon as $1 \mathrm{t}$ is avallable in the reglstration offlce, arrangements have been made with Mr. Tan to permit Mr. Dav1s of Kelly and Walsh, our agent in Singapore, to see the information at any time. This method will eliminate the delay of many months in our recelpt and ohecking of the quarterly registration lists in the offlolal Gazette and the subsequent canceliation of orders for the desired books found to be out of print or for some reason not avallable.

Reprints from the Gazette of the quarterly reglstration l1sts of books from September 1937 through August 1941 as well as all 1 ssued after the war-from November 1946 through October 1947-were furnlshed by Mr. Tan. At my request he also furnlshed a list of all perlodicals published in Singapore and all newspapers publ1shed in Singapore and the Federation of Malaya since October 1945.

Mr. Ernest TIpson, Becretary of the Brit1sh and Forelgn Bible Soolety furnlshed me with the New Testament and portions of the Blble in romantzed Malay. The ent1re B1ble in romanized Malay has never reappeared since the war. By a polloy of lons standing this Soclety publishes nothing except the Bible. All their printing 18 now done in Hongkong, rather than Singapore, beoause of the terriflc high cost of labor in Singapore; in th1s way a book can be produced for about half the prloe asked in Singapore. At present Mr. Tipson is compling a Chinese dictlonary based on the Shuo-wen dictlonary, whlch appeared 
about 200 A.D.y in which he alms to show the plctorlal derivation of Chinese characters. The book w1ll appear in late 1948 or early 1949 with the t1tle: Etymolog1cal and phonet1c dictionary, Chinese-Engl1sh.

While talking with Dr. Allen, President of the Raffles College Counc1l and appointed President of the future Raffles Unlversity, I learned that plans are under way whereby Raffles College and KIng Edward VII College of Medicine w1ll be merged Into a single educational unit and will be called Raffles Un1versity. The planning commlttee has stated that the new Un1versity w1ll not be located on the present site of Raffles College but w1ll be moved to some other spot in Malaya. The exact location has never been made publ1c by the committee. Mr. Oppenhe1m told me that he would keep me 1nformed as to the progress and the announcements of the committee.

Durling the years of the Japanese occupation, the College bulld1ngs were used by the Japanese as the1r m111tary headquarters. The College bulldings have been derequisitioned recently and the schooluts now operating much as before the war on a coeducational bas18.

A group interested in library matters in general and exchange of materials in particular had me out for tea at Raffles College. Those present were Dr. Opplnhelm, Mr. Cowan, Mr. B. Harrison, H1story and Dr. T. H. S1lccck, Economics. The t1me was spent in showing a number of the Library of Congress publications, leaming the needs of their library and laying the groundwork for exchange of publications. They showed particular interest and desire for the following Library of Congressu publications: the Catalog of Printed L/C Cards, b1bliographies dealing with Southeast Asia and the Far East in general, certain Publ1c Affalrs Bulletins and the U.S. Quarterly Book L1st. The fact that L/C cards mIght be purchased for the1r own library appealed th them very much. However, one wall 18 in the way of making any purchases in the U.S.; namely, no money can go out of Singapoure to the U. $S$. at the present timeu Unt1l th1s 18 taken away, there appears to be no way for 1nst1tutions of this kind to make purchases of any kind in the U. S. Any methods which do make 1t poss1ble to send money out of the country are looked upon as lliegal.

The Raffles College Library took a bad beating during the war. After the Japanese came in, a group of the faculty members --three of whom were at the tea mentioned in the foregoing paragraph--carefully selected about 500 of the best books of the library and took them up to Northem Malaya where they were carrying on the College in a certain fashion. The Japanese soon took these men up to slam and put them to wo rk on the Burma-siam rallway construction job. The books were of course left behind and were lost. Very few of the orlginal books were left in the Library after the Japanese departed. 
I was interested to learn that prior to the war there was exchange of books between the Raffles College and 1nst1tutions in Batavia on an interlibrary loan bas1s. Th1s has never been resumed since the war and these professors expressed a desire to learn what had happened to these inst1tutions in Java.

Wile in Singapore and Malaya the following addresses were glven: "Acquiring Publications in Malaya for the Library of Congress," a radlo broadcast in both Singapore and Kuala Lumpur; "Some Services of the Llbrary of Congress," at the Singapore Rotary Club; and "Un1versities and Colleges in Amer1ca," at Raffles College.

Following the speech wh1ch I made at the Rotary Club of Singapore, the Publ1c Relations Offlcer in the Singapore Government made the statement before the club that since there is such a storehouse of valuable information housed in the L1brary of Congress, steps should be taken by international agreements in the interests of cultural exchange between nations to spare such a valuable institution from destruction in case of another war.

In conjunction w1th purchases, Mr. Emmons, the D1sbursIng Offlcer, and Mr. Jossel yn, the Consulate-General, were both cooperative in providing funds on the letter of credit. US \$819.

The total amount expended InuMalaya was approximately 


\section{THE EAST INDIES}

After Singapore and the Federation of Malaya, the East Ind1es was next on my 1tinerary. On February 6th I arrived In Batavia, the Dutch cap1tal in westem Java. Knowing the political problem within that colonial area, I real1zed full well that my work would not be conflned to the c1ty of Batavia. If possible, I had plans for golng to Jogjakarta, Soerabala, Bultenzorg and Bandoeng. Also, I was determined then to secure publications 188ued by the Republ1can Government as well as materials printed in the Dutch language. Th1s was done and the findings during my four weekst stay in the Islands are included in the following report.

Through the courtesy of the Good offlces Comnlt tee of the United Nations, which 18 acting as an intermediary and advisory body in connection with the Indonesian question, I was granted permision to go to Jog Jakarta, the Republican Cap1tal in central Java, in the plane wh1ch that Committee operates between Batavia and Jogjakarta for the convenlence of those persons on offlclal business. Among the 25 passengers there were only 3 Amerloans: Mr. Dubo1s, the Amerloan representatsve on the Committec; h18 secretary; and myself. Most all of the other passengers were Indoneslans representing the Republican cause. Dr. Darma Set1swan, the ex-M1n18ter of Health in the Republican Government, showed great interest in my mission of securing publications for the library. Through him and others I was able to meet a number of the offlcials in Jogjakarta. Ch1ef among those who alded me was Mr. Natsir, the Minlster of Information for the Republican Government.u Even though $1 t$ was Sunday, he came down to h1s offlce and in a perlod of three hours he and others lald before me the publications 18sued by the Min1stry of Information. The material was published largely in Engl1sh; nothing in Dutah. Among these publications the following titles appear: Pol1tical Manlfesto of the Government of the Republ1c of Indonesia; donstitution of the IndonesIan RepubiIc; The Freedom of Indonesia; AIms in the Fac1f10; Minorities in the Republ1c of Indones1a: Rad1o speech of V1ce President Hatta, 21 February 1948; Do Know More About Indones1a; I'wo Tasks of Aliled Forces in Indonesia Fulfilled. A rather unIque acquisition on this trip was not a printed doeument but an album containing the orlginal drawings in oolors from whioh the Republican propaganda posters were designed. Being the only copy and never having been published, th1s album becomes all the more Important to the Ilbrary. About a week later Mr. Natsir supplied me with the large posters made from these miniature designs. The slogan of the Poster Division in the Ministry was "We struggle with Posters.U No plans were made for offlclal exchange w1th the Republican Government at JogJasarta since the United States has not reoognized that Govemment.

Wile in Jogjakarta, arrangements were made w1th the Republican News Agency, Antara, for the L1brary to recelve on 
an exchange basis the daily news sheet 1 soued by Antara. As far as 18 possible, back 18 sues of th1s news sheet will be furnlahed the L1brary.

Under the present conditions it is rather diffleult to secure publications from Jogjakarta on an orderly basis in the same manner that the Llbrary 18 able to recelve materlal from other c1t1es. There 18 no offlclal mall service and with the exception of the infrequent plane service made possible by the Good Offlces Committee, there is no travel communications. Only messages of a diplomatlc nature are telegraphed or radioed.

One Sunday night I had the pleasure of attending a dinner at the Republican Palace in Jogjakarta at the 1nvitation of Dr. Hatta, V1ce President of the Republic. Among the guests, I met these Republican leaders: Dr. Am1r. Sjarifuddin, a former Premler; Dr. Soedjarwa TJondronegoro, Secretary to Miniater of Information; A.J. Pringgodigdo, Secretary to Vice President Hatta; Mr. Assaat, Chalman of Indoneslan Provinclal Parliament.

One leading source for comme rclal publthations in the Indonesi an language 1s Pustaka Rakjat in Batav1a, which publ1shes books and pamphlets dealing w1th the h1story, 11 terature, religion and politics of Indonesla. The following titles will give an 1dea of what are 18sued: The H1story of the Indonesian Movement; Bank1nf; Problems in Indones1a; The Bas1s of Our Forelgn Polley; \& Sunda-Malay Dict lonary; The H1s tory of Indones1a; Pol1t1cal Sphere 1n Indones1a after the Proclamation: The History of the Struggle and Reconstruction of the Republic of Indones 1a.

The bookstores in the Indies were fllled with good books published prior to the war. The problem was one of selection. The only exception to this fact which I encountered was at Jogjakarta where there was a real scarclty. Of the places visited on the trip I think I secured the most material in the Ind1es, the majorlty of which was published in the Islands prior to the war and was found in the out of the way secondhand bookstores. I remember onesmall shop in Bultenzorg which I came across by accldent when out walking one sunday after noon. The stock which th1s man had in h1s shop and house was so very good that I concluded $1 \mathrm{t}$ must have been looted mater1al. Anyway, 1t 18 not stolen now but has been purchased for the L1brary: dictionarles, books on orch1ds, othonology, h1story, agrlculture, geography and other subjects. In all, I was sur prised to 1 ind so many of the works of Stuttenhe1m, P1geaud, van der Hoop, Ochse and other Ind1es authorlties which the L1brary did not have.

When In Soerabala, I met w1th Mr. C. Ockeloen, Manager of the Kolff printing $11 \mathrm{rm}$ in that c1ty. Prior to the war he prepared a number of publications of real value to blbllographers interested in the Indles. Fortunately, the following were st1ll 
avallable: Catalogus van bosken en t1.ldschriften u1tgogeven in Nederlandsch 008t-Ind18 van 1870-1937, (1016 p.); Catalogus darl boekoeuboekoe dan Mad.lallah madiallah lane diterb1tken d1 Hindia Belanda dar1 tahoen 1870-1937; and Catalogus van in Nederlands ah Ind1e versohemen boeken in de Jaren 1938-1941, vol. I (1942). He 1ntends to resume theuvaluable prewar publication Nleuwablad voor den boekhandel in Nederlandsch 0ost Indie, which w1ll give general information concerning the new publications 18sued in an about the East Ind1es. He supplied me with all the publications which he has 1s8ued since the war including materials in the Javanese and Malay languages. Mr. Ockeloen also furnished me with much valuable information regarding the book trade in the Ind1es, and the plans he 18 now initiating with the purpose of organlzing all book dealers who handle Indoneslan publications. He also has plans well under way to relssue the Atlas van Troplsch Nederland under the new tltle Atlas of the United States of Indonesia with the hope that $1 t$ will be ready by somet1me in 1949.

After a survey of the responsible bookdealers in Batavia Kolff, Von Dorp, V1sser and Wolters, I selected Kolff and Co., to act as the agent for the Llbrary of Congress. It was here that I found not only many books whlch were wanted for the Ilbrary but also a cooperative splrit which alded me 1mmeasurably in getting 1nto touch with Government officials and others in varlous institutions. As in the case of the designated Llbrary agents in the other countries, a statement has been provided Kolff and Co.u explaining what the L1brary desires by way of materials and Information as well as the nature and ship ment of the publications from the East Indies.

In Batavia I v1sited one of the largest printing and publishing establishments in the Far East: Kolff and Co. The name of the General Director $18 \mathrm{Mr}$. E. J. Terway, who took me through the many bulldings which comprise the $11 \mathrm{rm}$. Three facts 1mpressed me as I went through the plant: ( 1 ) the $81 \mathrm{ze}$ : there are nine large bulldings in which are employed about 1,000 people working in the various departmentsp the IInotype, book printing which 18 set by hand, poster and label printing, block designing and making, drafting and sketching, currency printing, binding, paper storage, and other departments. Even with this many employed there 18 a shortage of wo rkers drawn from the Indonesians of the country; hence, there 18 no unemployment problem at the present. The greatest need, however, 18 for technical men from Holland, who are being secured as rapldiy as possible. (2) The manlfold production: the largest and most lucrative work 18 that of the printing assignment recelved from the Government whereby they print the paper money, postage and revenue stamps, post cards and a1r letter forms, all statlonery supplies as well as 95 per cent of all Government publications. The reason for Government printing being done by a commeurcial concern on a concession basis 18 that the Japanese all but completely rulned the Government establishment. 
It appears that 1t w1ll be somet1me before the Govermment w1ll be able to resume that responsibllity 1tself. Furthermore, Kolff and Co. does a tremendous amount of printing and carton production for commercial concems--Iux and Lifebuoy to mention two American products--producling millions of boxes ready for the commerclal produot. They are equipped to print in $81 x$ colors. Although not on as extensive a scale as the Govermment printing and commerclal printing, perlodicals and a weekly newspaper are also printed here. The weekly summary of the text of an Amsterdam newspaper 18 flown out by KLM Constellation and in two days 18 belng printed by Kolff in Batavia. After the Dutch retumed to Java, Kolff also printed and published Het Dagblad, the leading dally in Batavia, unt1l the regula.r newspaper IIr got back on 1 ts feet to take over 1 ts publication. T1me and Ilfe approached this company for the printing of the 1r overseas editions for th1s part of the Orlent. The job was turned down, at least for th1s year, unt1l they had more technlcal personnel and ealpment from Germany and Holland. Although J. B. Wolters print most of the textbooks used in the Indles, Kolff also does some publishing of schoolbooks. (3) The rapld way in which the $11 \mathrm{rm}$ has come back after the war: Th1s 1s largely due to the hard work and wlse management of $\mathrm{Mr}$. Terwey, who goes to Holland frequently for the purpose of securing more skilled technlclans for some speclallzed part of the business. In the flrst part of September 1945 when he got out of concentration camp and retumed to the establishment, he found the Japanese had not destroyed the mach1nery and other equipment but had abused 1t badly, largely through the use of bad oll or no lubricant at all. Every machine in the entire place had to be taken down, thoroughly cleaned, new parts installed and assembled again. Th1s work 1s st1ll golng on. The bulldings were in good condition with the exception of the front parts which were damaged from shootIng by the Indoneslans after the Dutch returned.

At the Kon 1nkl1jk Batavlaasch Genootschap van Kunsten en Wetenschappen I had a conference w1th the Director, Dr. A. M. J. van der Hoop, in connection with a continuation of the exchange of publications whlch the Soclety and the Llbrary had enjoyed before the war. Among the postwar Llbrary publications, the U. S.-Quarterly Book Ll st took h1 s speclal attention; likew1see the southe Ast AsIa bIbIIography. As Director of the Soclety and Museume he displayed considerable interest in the 1dea of microfllming, and $1 \mathrm{~s}$ in hopes of securing equipment in order to have microflim facllitles for scholars in the East Indles. While theree I met the new librarlan of the Soclety, Mrs. Vreedede Stuers, who gave me the following publications for the Ilbrary of Congress: Geroneografeeede Catalogus der worken betreffende land en volk van Indoneslae 1938; Lilist van aanwinsten over het āâr 124le and Daftar buku-buku jang bertalian dengian Agana Iselam, 1947-all of wh1ch will be valuable blbllographlcal tools forethe Library,

Arrangements were made w1th $M \dot{r}$. van der kollen, the D1rector of the Aneta News Agency, whereby the Library of Congress 
w1ll recelve on an exchange basis the Indonesian-Section of the Aneta News Bulletin in English and in return the L1brary will send specifled publications lsoued by the Ilbrary. Belng one of the most 1mportant news sources, the Bulletin is being sent weekly by alr mall. Because of a paper shortage only enough coples to supply the dally clrculation are 1ssued; hence, I was unable to secure the back 1 ssues of th1s News Bulletin.

A complete flle of Sar1 Press (Press Summary) 1ssued by the Republicans was recelved from Dr. Madlono, the Head of the Indonesian Information Service in Batavia. The Llbrary will recelve this publication on a continuation basis.

Through the ald of Raden H1lman Djajadiningrat, the C1v1l Governor for West Java, I was put in touch with the proper authorities at Bandoeng to secure the documents in connection w1th the recent West Java Conferences. Since October 1947 there have been four sessions held in Bandoeng for the purpose of setting up the adminlstrative machinery of the State of West Java wh1ch henceforth w1ll be known as Pasundan State. I secured personally from Mr. J.uM. J. Morsink, the Resldent at Bandoeng, the entire set of proceedings of the f1rst three sessions. The proceedings of the last conference wlll be sent as soon as they are avallable. The Resldent was pleased with the 1dea of setting up an exchange between the Ilbrary and the new State whe reby all future unclassifled documents 18 sued by the State will be sent to the Ilbrary of Congress. The exchange arrangement has been conflrmed by letter.

While in Bandoeng, I met w1th the Director and Ilbrarian of the Geological Museum and established exchange relations w1 th th1s agency of the Government wh1ch 18 sues the Bullet1n of the Bureau of Mines and the Geological Survey in Indonesia, vol. I, no. I, being 18sued in March 1947. Th1s postwar ed1tion replaces the Volcanological Bulletin and the Kwartaalverslagen whlch were Formerly pubIlshed as a supplement of the Javasahe Gourant. A copy of U1teaven van den dienst van den milnbouw In Nederlandsch-Ind1e, 1900-1239 was glven to me foruthe purpove OI de termining what $1884 e s$ of the1r publications are missing in the Library of Congress. Those desired w1ll be gladly furnished $1 f$ the stook permits.

A visit to the offlces of The Economlc Review of Indonesia 1 ssued by the Dspartment of Economic Affalrs made 1t possible to arrange with Mr. L. R. Stallinga and Mr.ut. Erle Power the recelpt of this postwar monthly by the Llbrary. Back coples of the serlal for 1947 were also provided.

The General Agricultural Experiment Gtation at Bultenzorg has close afflliation with the following Government operated Inst1tutes or research bodles: Inst1tute of Applied Botany, Inst1tute of So1l Research, Inst1tute of Plant Diseases, Botan1cal Inst1tute, Agricultural Inst1tute and the Laboratory for 
Freshwater Isherles-all of whlch contribute solent1110 papers to the varlous publications 18 sued by the $G A \mathbb{S}$. Dr. C. van der Glessen, Head of the GAES, and Mr. A. van Leer, Librarlan of the Central Llbrary of Natural Sclence, assured me that the Ilbrary of Congress would recelve regulariy thelr publications: Bulletin of the Botan1c Gardens. Series III (formerly Bulletin du Jardin Bo tan1que de Bultenzorg), Treub1s, Mededeelingen van het AIgemeen Froefatation voor den Landbouw and the finnals of. the Botan1c Gardens, Bultenzorg. Satisfactory arrangements were made for the exahange of publications.

Mr. van Leer made the urgent request for books and Information on up to date 11 brary procedures and would l1ke to recelve the Library of Congress Handbook of Card D1stribution, Rules for Descrlptive Cataloging as well as any other information on reorganizing librarles along more modern lines snd any publications glving solentiflo blbllographical materials.

While at the printing establishment where a number of Government publications are printed in Bultenzorg, I learned that these publications probably will be published soon:

Annals of the Botan1c Gardens, [Bultenzorg]. Archlel voor de the culture in Nederlandsch Indie Eublished by the central union of the offlcers of the experiment 8 tations in the East Indies

Tectona. Boschbouwkund1g T1jdschrift (Forest Journal). L(Bütenzorg: Bosbouw proefstation. lst 1ssue since war, Vol. 38,1948 , now belng printed.) $J$

Chron1ca Naturae LBatavia: II Koningsplein Zu1d. (Sclence Journal of the Netherlands Ind1es) $)$.

An 1mportant document to those interested in sclentific work in the East Ind1es 18 Werkprogramma van het Algemeen Proefstation voor de Landbouw 1248, 188ued by the Department van Economische Zaken, presents an account of the enomous number of experiments and projects being carried on throughout the laboratorles and 1nstitutes in the Department.

While in Bultenzorg it was a pleasure to visit the famous Botanlcal Gardens where the flora of the Indies and other troplcal lands 18 systematically collected and arranged.u I was informed that during the Japanese occupation these gardens were declared Imperial property and were undor the protection of the Emperor. As was the case with the library of the Royal Batavia Soclety and the Llbrary of the Geological Museum at Bandoeng, the Japanese kopt intact the Central Library of Natural Sc1ence as well as the zoologlcal library whlch was moved to the new physlological laboratory bullding.

The Dutch Government in Batavia is still a long way from the organized status wh1 ch $1 \mathrm{t}$ had before the war. At present thore is a minlmum of coordination between the varlous Departments. In view of this condition I was not as successful as in 
Burma, Singapore and Malaya in making the arrangements for the exchange of officlal publications. Th1s 18 what was accomplished: (I) I met with those individuals who were connected in any way with an exchange of publications; namely, Mr. K. F. Verboeket, special advisor to the Governor; Dr. J. Osinga, Director of the Govermment Information Service; Dr. A. Seret, Head of Documentary Department in the Information Service; Mr. H.uJ. van Kleef, Office of Bala1 Poestaka; (2) A list was complied which gives the various Government Departments, their respective heads and the publications 1ssued by these Departments; (3) Since there was no centralized printing office, I approached the top officlals in the Information Service with a plan whereby an exchange of official publications might be established on an informal basis. In short, they would: (a) secure the publications which are 1ssued by the Government Departments located only in Batavia; (b) see to 1 t that all these materials were assembled and shipped to the Library of Congress; and (c) arrange for the transmission of future Government publications issued in Batavia--including serials--to the Library. Since my return, word has been received from Mr. Seret that the proposal was satisfactory and a number of the Government Departments already have shipped materials to the Library.

While at Regeerings Voorluchtings Dienst (RVD), Government Information Service, Mr. Seret fumished the Ilbrary all avallable publications which they have 1ssued since the war. Included in these materials are these 1mportant titles:

The Indonerian problem: facts and factors (1947)

The other slde of the medal; addresses delivered by the Neth. Representative in the securidy Counc1l of the Un1ted Nat1ons. Nin. $\bar{E}$. N. Van Kleffens. durine the discussions of the Indonesian Question (Julv 31Isugust $26,1947 T$. - 1947

100 pages Indonesian economics. (1947)

Whatls $1 \mathrm{t}$ about in Indones1a. (1947)

From Enpire to Union: an Introduction to the H1story of the Ne therlands-Indone gi an relations. (1947)

Denpasar: bouwt an hulsu (1947)

Indonesie in het Parliament Ne1 1946 (1946)

Comm Isiar 1s8en-Generril over de Ontwerp-overeankomst (1946)

Besides these, coples of the proceedings of all the Dutch-Indonesian conferences at Denpasar, Pangkalpinang and Malino were secured.

Complying with my request, 29 photos of the three West Java Conferences at Bandoeng were supplied by the RVD in Batav1a. Arrangements were also made with the Information Service to have the dally press digest 1ssued in both Jutch and English sent to the Library. In th1s same offlce M18s Bettink made avallable to me a lengthy list of the newspapers and other serials published in the Indies in the Dutch, Indonesian, Chinese 
and other languages. W1th th1s 1nformation and w1th the data secured wh1le in Jog Jakarta I have a good plcture of what 18 belng published in the way of serlals. Through Kolff and Co. subscriptions were entered for the leading newspapers and perlodicals 18 sued in Batavia and other cities in the Islands in the Dutch, Indonesian and English languages.

Mr. Willard Hanna, the Public Affa1rs Offlcer and Mr. John Naliy, the USIS Llbrarlan, were cooperative in supplying information regarding booksto res, publications, government offices and cultural institutions. The USIS office and I1brary have been opened recently in Batavia, and Mr. Hanna and Mr. Nally are managing the project well so that the influence of the services of fered $1 \mathrm{~s}$ belng felt throughout the c1ty. Mr. James Gould, an offlcer at the American Embassy, made possible transportation for all of my offlolal business, and took charge of the shlpment to the Ilbrary of Congress of the materials acquired in the Indies. 


\section{INDOCHINA}

My arrival in Indochina came just the morning after two Americans in the Consulate-General were killed near Salgon. Clvil conditions in the country were probably the worst of any country I v181ted. The V1etnamese and the French were st1ll carrying on actual military action; no settlements seemed to be near at hand; the Communist elements were making the most of the situation. Wile landing at the salgon alrport, one could hear the shooting of sk1 rmishes in the distance. Although I was unable to secure any publications from the Vielinamese in viet $\mathrm{Nam}$, on the whole the acquisitions were worthwhile in Salgon and Hano1.

As would be expected, the number of offlc1al publications now being 18 sued in Jndochina are not too numerous. Arrsnge-

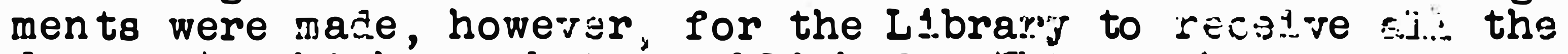
documents which are being publ: hode ingis excharge afreement was made on an informai fias 18 wliticlit the officia! rivteis. Before leaving the offlce of $M$. de la Fourstere the disrectior of the Bureau de la Presse et de I: Informaticn, I secured ccples of all the followlng publisations and delivered them to the Consulate for ehlpment with the ot ar materiais procured:

Journal officjel de liInanchine; Journal cificted de ia Pepub-

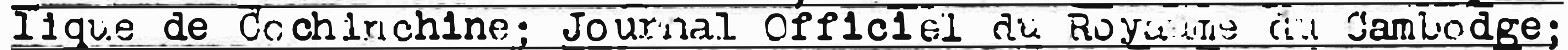
Bulletin fdmlris stratif du Cambudge; Bulittin inf́-giei du comm18sar1at de Iz Repilin1que pour le Sud-Annam; EajJ.erin off1c1ele

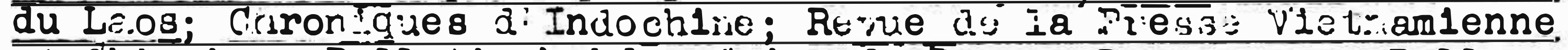
et Chino18e; Bullet1n heudomadalre de Preese Econorique; BulleEIn Econom!que de I! Indouhine; La Conferunce de Daist: S1tuation en Indochine. Al18t of certain basic offlcial douinents dealIng with Indochina was left with $M_{n}$ la Fourniere who stated that he would secure for the Llbrary whatever were avallableu The l1st included: Journaluofflelel de 1 :Indochine, Bac-ky' hao-ho, quoc-ngu cong-bav, and namtrien, quoc-ngu cong-bao.

While talking with M. de la Foumlere, it was leamed that plans are belng made for recording the folk music of Indochina. Since he recelved h1s education in America and 18 interested in the recorded folk music of Ameurica, it 18 not $1 \mathrm{mpos} 81 \mathrm{ble}$ that an agreement might be arranged so that the Library could recelve on an exchange basis this recorded folk mus1c when 1t becomes a real1ty.

Another 1mportant exchange agreement was w1th the Musee Blanchard de la Brosse of whlch M. Louls Malleret 18 the Secretary-General.u From this leaing cultural institution of Salgon the L1brary will recelve regularly the Bulletin and other publications of the Soclete des Etudes Indochino1ses. Like the Ecole Francalse d'Extreme Orlent in Hano1, tho Soclety continued the publication of 1ts Bulletin throughout the war and therefore fumlshed me with th1s publication 18sued since 1940. The two volume Catalogue gencraludes collections was 
also presented to the Llbrary. Mr. Malleret supplied me w1th information relative to the classiflcation of Annamese proper names.

A conference w1th Mr. Maurlce Bayen, the Rector of the Unlversity de luIndochine, disclosed a number of facts regardIng the program, faculty, students and publications of the University. As stated in another plaoe, the University lo now divided between Salgon and Hano1; the Faculty of Medicine and Pharmacy belng at Hano1, wh1le the Facult1es of Law, Education, and Letters and Technology are at Salgon. The serlal ent1tled Education will carry soon an article by $M$. Bayen glving a plcture of the UnIvers1ty and 1 ts present activities. Back coples of th1s monthly were secured and exchange arrangements were made for this and other publications 1ssued by the Un1versity.

Mr. Paul Boudet, D1recteur des Aroh1ves et des B1bl10 theques de l'Indoch1ne, and well known for h1s Re la B1bl1oEraphie de l'Indochine Francalse 1913-1923. 1927-1929 and 1930 and Deul'I conographle h1storlque de l'Indochlne (1939), alded me conside rabiy in securing materlal from the l1brary at Hano1. Furthermorey at my request, he provided information regarding the classiflcation of Annamese proper names. Th1s w1ll be valuable guldance for cataloging Annamese materlals. With the purpose of establishing a photoduplioation service for the Arch1ves and L1brarles in Indoohine, $M$. Boudet placed with me a written request for particular inforwation regarding m1crof1lm and photostat methods and equipment.

As with books, the number of serlals belng 1ssued were not numerous. One of the best post-war joumals 18 FranceAsle edited and published by an enterprising and 11 terary per-

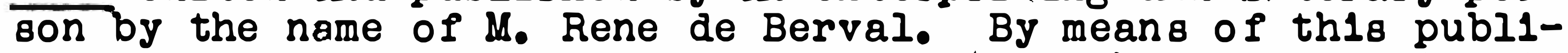
cation one w1ll be able to keep abreast of the cultural inst1tutions and I1terary writers of Indochina. A complete file of the monthly was secured in conjunction with the exchange agreement wh1ch was arranged between the I 1 brary and $M_{\text {. }}$ de Berval. In exchange for the back ooples the editor requested that the Llbrary send h1m, if possible, a copy of Who's Who in America and International 'Tho's Who.

Through the courtesy of $M$. de Berval I met $M$. Georges Vial-Mazel, cultural attache to the H1gh Commissioner and one who 18 an authority on French-Japanese relations. He provided me w1th the following unpublished documents: La Kempeta1, Gestepo Japonalse, Relations Pollt1ques Franoō-Japona1ses and BuIIetin des Ecoutes Radjotelegraphiques de SaIgon.

W1th reference to the praotloe of law and legal publications in Indoch1na, I was unable to secure any extensive information. However, contact was made wlth $M$. Kherlan, Dean of the Faculty of Law In the Unlversity of Indochina, now located 
at Salgon. He w1ll be able to asstst our Law L1brary in the future. The law joumal now being 18sued 18 Journal Judicalre de I'Indochinel

Finding 1t 1mpossible to go to the Service Geographique de I'Indochine located at Dalet, I secured information by correspondence from the Director regarding the maps currently 18sued. Through M. Franco1s de V1lieno1sy, Directeur du Cadastee in Salgon I was given information about a small sheet: Tableau d'Assemblage des Cartes de I'Indochine an 100.000 (1948), which in turn was secured from the service in Dalat.

Through the Offlce of the High Commissioner located in Salgon my request for travel to Hanol was granted w1thout delay. The trip was by A1r France, which 18 the sole transport between Salgon in Sud Viet Nam and Hano1 to the north. Hano1 used to be the seat of the French Government but the colonlal war has necessitated the Government to move to Salgon. 01 all the c1t1es I saw on my trip which recelved bombing--Rangoon, S1ngapore, Batavia, Soerabala and Manila-Hanol was one of the worst. From the almport to the town there was mile after mile of battered bulidings and areas of devastation. The road which was completely fliled with large ch uckholesu was one evidence of the war there. That w1ll be one jeep ride I w1ll not forget. The town was in such a terrible condition that I think $1 t$ will be a long time before $1 t$ will be the busy and 1mportant c1ty $1 t$ was prior to the war. One was aware of the lethargy whlch seemed to control the place.

While in Hano1, I saw the following places and people: (1) Imprimerie d'Extreme Orlent (IDEO)y which used to be one of the largest publishers in Indochina and before the war had a printing establishment only rivalled by Kolfe at Batavia in the Far East. The entire printing plant whlch used to be located out near Lac de Truc-Bach was completely destroyed in December 1946 together with all machinery and other equipment. The present plan 18 to have the main business offlce in Hanol but a complete new printing establishment 18 being started in Salgon. New machinery as well as printing techniclans have arrived from France and other countries; by the end of 1948 the $y$ ought to be publishing and printing once agaln. The General Manager whom I met was M. Leboff.

(2) Ecole Francalse d'Extrome Orlent (EFEO) of wh1ch Mr. Paul Levy 18 the Director. For some years this institution has been an important agency in the flelds of archaeology, ethnology, anclent history and allied subjects deallng primarliy with Indochina. One of the most 1 mportant functions of this culturnl center 18 the publishing of scholarly studies and other valuable documents in these special plelds of resenroh. Among the publications 18 sued, the most lmportant is thelr Billetin (BEFEO), whlch 18 a mine of information for the ethnolog:st, anthropologlot and archacolog18t. Also there are tho Pubilcation Serles 
wh1ch are more extene1ve than the papere in the Bulletin. The publicatione lesued eince 1940 include the following: Bip 20 , vols. 38-42; Reohorohee preh1otorlques dane la reglon de MluPre1; Recue1l des ooutumes rhade日e du Darlao; Rocuell der chante de marrlage Tho de Lang-Son: CahIers de I Eoole Francalce T'Extreme Orlent; Inventalre du Fonds chinode; Bulletin I' Inot1tut Indoohino18 pour l'etude de l'Homee (BIIDH), vols. 3-6. दII of these publioations were taken by alr from Hano1 to salgon olnce alr 18 the only method of ohlpment from Hano1 at present. Scores of other packages were ready for malling to many smerlcan Inst1tutions, but certain postal regulatione regarding welght of parcels prohlbited their leavir. Hano1. Th1s 1nstetution has been on the exchange l18t of tie Llbrary for some years and would like to recelve as complete Plles as poselble of the publ10atione which have been 18eued einoe the war started. AooordIng to Mr. Levy, 1 te otocks of plit: seations remalned untouched during the war. Furthermore, 1 to publishing activities have been oontenued and etocks of the wartime publloatlons are avallable to any inet1tutione desiring to open exchange relatione.

The Japanese apparently used the oame polloy toward th1e library which I found they emploved in other oenters; nemely, of proteotion rathor than destruution. I was shove the notable collection of Orlental material in the library whloh has many MSS In Cambodian, LaOB, Burme日e, S1ame日e and Chinese. Up unt11 early 1946 it was 1mposelble to procure any DDT with which to combat effeotlvely the ever precent ineeot danger in the trop1ca. All books in the library are nor dueted methodioally with DDT.

During the V1et Nam oonfliot in late 2945 and early 1946, the sahool lost a great doal of 1 to photographlo equipment, most of Whis was looted. Aooording to ur. Jean Manikue, in charge of photoreproduotion, the emaller camerae were taken but only the lenees of the larger oamerae. An at tempt has been made to replaoe this lost equipment but Eaotman branches in India and Australla do not stook their needs. He provided mo with a complete 118t of the materlale desired and requested me to contact Eastman in Roahester regarding the problem. They are also keenly interested in mlorolilming and would like to install the neceseary equipment. The information will be oent.

The Director was interected in plaoing a etanding order for current carde on the eubject of Boutheast Asla a well ae a oomplete cot of the Ilbrary of Congrese printed carde dealing with this eame region. I was aksed to take up the matter with the Card Divielon.

(3) The Loule Finot Kuseun 10 undamaged. Bome valuable objeote. Bold and ellver, rere looted but on the wolo the mueeum ouffered very 11 ttle. While I was there, objeote wioh had been etored in eubterranean vaults wore belng reaceombled for exhibltione. A large number of the pleoed liluetrating varlow oulturos in the muserm were acquired from expeditions in different parte of Indochina, Cambodia, Ohina, Blam and Burma. 
(4) Another 1nstitution which made Hano1 a cultural center before the war was the University of Indochina. Of the facult1es whlch formed the University at that time, the faculties of law, letters, and education were removed to Salgon, leaving only the faculty of meảlcine in Hano1. In a conference with Dr. Huard, the Dean of the Faculty of Medicine, arrangements were made for an exchange of publications. To my great surprise there have been 18 sued a number of studies in the fleld of med1clne during the past few years. A complete $118 \mathrm{t}$ of these publications has been recelved from Dr. Huard. Unfortunately they were not ava1lable for me to take out by a1r, but will be sent to the L1brary when possible. Many of the monographs were prepared by Annamese medical men. In retum for the se, Dr. Huard would like to recelve any publications in his fleld of mediclne. I assured hlm that any U. S. Government publications which would be valuable for their medical library would be sent. He was particularly interested in recelving, if possible, the recent 1 ssues of the Quarterly Cumulat1ve Index Med1ous 1ssied by the American Medical Association. I 1ntend to approach the All on h1s behalf. The latest of th1s work in the $1 \mathrm{r}$ medical l1brary was vol. $29,1941$.

(5) At the Archives and B1bliotheque de I'Indochine, Hano1, of wh1ch MIle, de St. Exupery 18 the Assoclate Director, the following materlals were recelved: L'Indochine dans le passe by Boudet; L18tes des 1mprimes du dopot Iegal; ReceueIl general. de la legislation et de la reglementation de luIndochine; Annualre administratif de l'Indochine. Encouragement was also given that possibiy the additional material which I had requested for the Library would be avallable in a few monthsu From the sets which they have of the Joumal offlclel, first must be met the needs of the Government offlcers in tue and other places where Government documents have been destroyed. A letter of further inquiry at a later date would be w1se. The material 18 there, for I saw 1 t in the stacks during $m y$ tour of the library.

A Portall \& Co., Rue Catinet, in Salgon, was selected as the Library of Congress agent in Indochina. Compared with the other countries there were relatively few publications whlch have been 18 sued in the past two or three years. Portall fur nlshed me all that were avallable. Among the books purchased in Salgon and Hanol the following are 1mportant: Etude sur la 11t terature Annam1te by Georges Cord1er. (1940); V1et nan Van hoa: Elu-ouong (Esquisse d'h1stolre de la clv1lisation Annamite) by Dao-Vuy-ann. (1938). Le Probleme Franco-V1etnamion by NguyenWhac-Ve (1 947); Accords Economlaues Franoo-Jadona1s relat1fs al'undochlne (1941); Viet-name Kink-Te Iuoc khao (Economice of VIet Nam) by True Ch1 (1947): Nouveau Reoue1I de Leg1slation Cantonale et Communale Annamite de Cochlnchlne by Erreot Outrey (I92ठ): H18to1re des nays de ITUnion Indochino1se by Nguyen-vanque (1933); Pour m1 cux comprendre Angkor by Geo. Coedes (1943).

The letter of oredit was not used in Indochina since the management of Portall requested that the Library make all payments to their agent here in Amorioa. 
The Ph1lippines was the last country visited on this trip. Arriving in Man1la on March 30th, I was met at the a1rport by Dr. and Mrs. Fre1, personal frlends, Prof. Bernardo, Llbrarlan at the University of the PhIllppines, and Mrs. Yoder, Ilbrarlan at the USIS--who were of valuable assistance in locating and evaluating publications in the 1slands. Plans had been made to visit the publication centers at Dumaquote and Ilo1lo C1ty but were cancelled within ten days when 1 t was clear that there was more than enough to be done in Manila.

Within a week after arriving in Manila, arrangements were being made for the desired international exchange of official publications between the Govermments of the Republic of the PhIllppines and U. S. I had been Informed of the fact that according to the U.S. Code, Title 44, Section 89, the U. S., prior to the war, had sent 1 ts offlcial documents to the Philippines but there was no arrangements for reclproclty. I was interested to note the fact that the Forelgn Offlce of the Ph1lippine Govomment had sent a message to the Amerlcan Embassy objecting to the statement from the Government Publications Offlce in Washington which sald that U. S. documents would no longer be delivered since the Ph1llppines had become an 1ndopendent country. A definite request had been made for the continuation of the delivery of U.S. offlclal publications to the PhIlipplne Government. Therefore, long oonferences w1th Mr. E. B. Rodriquez, the Head of the Bureau of Llbrarles as well as Head of the department handling exchange, Mr. Pablo Lucas, Director of Printing, and Dr. Afrlca, Undersecretary for Forelgn Affalrs, were not necessary. Mr. Meador, Publlc Affalrs Off1cer, was the person in the Amerlcan Embassy who accompanied me when laying the groundwork for the exohange. It was through this offlce that the officlal note was sent from the American Embassy to put into effect the international exchange agreement. In view of the practice prior to the war, coupled w1 th a written request from Mr. Rodriquez for all offlclal documents, $1 \mathrm{t} 1 \mathrm{~s} \mathrm{my}$ Judgment that a "complete set" rather than a "partlal set" of public documents should be sent to the PhIlippines in conjunotion w1th th1s exchange.u

The USIS Library in Manila was the largest I saw during the trip. It was belng most efflclently operated under the direotion of Mrs. Yoder. She 18 a person of genuine ablilty for the manlfold duties which fall upon her from day to day. At these he adquarters on Escolta I established my offlce and recelved cooperation of highest callbre. Ready Infoumation concerning the location of Government offices, bookstores, and newspaper publishing plants was at my disposal.

As in the other countries of Southeast Asla a rellable and competent bookdealer was engaged in Manila to act as the Library of Qongress agent for materlals from the Ph1lippines. 
The name of the f1rm is the Advocate Book Supply Co. Azcarraga Street of whlch Mr. Pedro B. kyuda 18 the manager. It was only after careful consideration of a number of possibilities-ancluding the Ph1l1ppine Education Oo. and the University PublishIng Company--that the cholce was made. Mr. Ayuda 18 a law school graduate and recently galned entrance into the Bar Assoclation of Man1la which accounts for his abli1ty in supplying the largest amount of legal material whlch was in his shop. Furthermore, he makes a speciality of collecting old Filipinians. A detalled written statement was drawn up whlch stated the responsibilities of the agent. In accordance with the written request of Mr. Ayuda, the Llbrary 18 to make all paymentr due the Advolate Book Supply Company to the Prent1ce-Hall publishers in New York.

The largest percent of the material secured in Manila was purchased from this f1rm. Among these books were the following for the Law Library and the general collectionsw

Criminal Law: Revired Penal Code Annotated by Ambrovio Pad1lia (1947); Notes on Confllet of Laws by Tadilia (1946); Commentarias and Opinions on the Constitution of the Philippines by N. V. Viliaruz (I935); The Ph1l1ppine Law of Private Co mporations by C. R. Carlos (1946); Commentarles and Jur1sprudence on The Commercial Laws of the Philippines, 4th ed. by Arturo M. Tolentino (1947); Philippine Law Journal; Forces that Make a Nation Great by Jose P. Laurel (1943); The Ph1l1ppine Educational System Its Foundation and Practice by Antonio Isidro (1947): The Government of uthe Repubilc ofuthe Ph1l1no1nes: Orialn. Development, Organization and Functions by Arturo Tolentino (1946); Report on Commun18m in the Ph1l1ppines by Maximo C1ron (1946); 1948 Commercial and Trade Directory of the Philippines (1948); The Reconstruction of Lost and Destroyed Documents and Records by Salvador DeTagle (1945); Pol1t1cal and Soc1al H1story of the Ph1l1ppines by Gregor10 Za1de (1947); An OutIine of PhIl1ppine Soclal I1fe and Progress by Franc1sco Pac1s (1946).

Economically the municlpality of Manila has made great strides. Through the amed forces of the U.S. millions of pesos have been spent in the program of reconstruction, and thousands of Filipinos have been employed for bullding or repalring roads, bridges and bulldings. The most 1mportant publication relating to the economic $11 f$ e of the nation and the period of reconstruction 18 the Beyster Report. Th1s Report, ent1tled Proposed Program for Industrial Rehabilitation and Development ofuthe Republic of the Phillpplnes, was prepared by the Technlcal Staff of the National DeveIopment Company under the supervision of the $H . E$. Beyster Corporation of Detro1t, M1chigan and was 18sued in Manila in October of 1947. It was a study made as a part of the progressive program of reconstruction inltiated by the late President Roxas. 
Japanese publications 1ssued in Tokyo prior to the war by the Kokusa1 Bunka Sh1nkoka1 (The Soc1ety for International Cultural Relations) were brought to the PhIl1ppines and distributed freely as N1pponese propaganda. A few numbers of the serles were found In Manlla in private collectlons: The Development of Econom1c L1fe in Japan by Takao Tsuch1ya; EducatIonal and Cultural Background of the Japanese People by Nyozekan Hasegawa; Anclent Japan in the L1ght of Anthropology by Ryuzo Tor11; The Orlginal1ty of Japanese C1v1l1zation by Arthur Waley; Japanese Muslc by H1sao Tanabe. A few Japanese publications having spec1f1c connection w1th the Ph1llppines were provided by Prof: Beyer from the collection at the Unlversity of the Ph1llppines. Among these was a study in a serles of monographs subm1tted to the Research studyuin Comm1ssion on the Philippines under the Adminlstration of Commanding General Tanaka ent1tled A H1storlcal Survey of Pollcles pursued by Spain and the U.. Toward the Moros in the Ph1l1pp1nes (19374) prepared by - A study prepared by Dr. Beyer at the request of the Japanese was Christian Population of the Ph1lippines in 1942 ; published in Japanese in 7 parts in two ed1tions (1942, 1943): A third book was the Addresses before the Assembly of Greater East-Asiat1c Natione, consisting of the speeches by U Ba Iraw, Osnena and other polltical leaders in Southeast Aslay delivered in Tokyo in November, 1943. A copy of Souvenir P1ctorlai of the B1rth of the Philippine Republic was presented as a fift to the LIbrary by Mr. Frank Zaldarriaga of the USIS L1brary.

Prior to my arrival in Manila, Mr. Frel secured from the Manila Post offlce a list of the publications entered as second class mall in Manila and the Provinces, Upon checking the 11 st with bookdealers and others, I made a few correctlons, but on the whole the 11st was rather accurate. The city of Manlla was producling more serlal publications than any other center in Southeast Asla. After careful conslaeration of th1s list of 221 serlals, 10 newspapers and 22 other serlals were subscribed to through the Ilbrary of Congress agent. Through the arrangement made w1th the American Embassy in Manila, the Man1la T1mes, the Man1la Dally Bulletin and the Amerlean Chamber of Comme ree Jour nal are to be sent to the L1brary via the Embassy weekiy alrmall pouch: Alluof the rest will be sent via the Embassy sea pouch. The agent will send samples of numerous other serlals for which no subscriptions have been placed.

As in Singapore, c1rcumstances proved favorable in Manila for the acquisition of both serlals and books publushed during the war. There were complete flles of three newspapers 18sued during the Japanese occupation wh1ch were procured by barter rather than by purchase. (1) In the case of the Man1la Tribune an agreement was arrived at whereby the Llbrary would recalve bound volume 8 of the Tribune--from January 3, 1942 to February 34 1945--comprising the complete flle, in return for which the Ifbrary would glve the donor a mlcrofilm copy of the paper plus a microfilm copy of certain documents now in the I1brary in connection with the F1lipino Revolution in 1898. Over and above 
the newspaper, the Llbrary al so recelved coples of Japanese propaganda posters. As a point of information, it should be sald that another flle of the Manila Tribune was discovered in the course of my search for materlals. The owner wanted P2300 (\$1150) as h1s f1rst price and close to the time of my departure lowered the selling price to P2000 (\$1000). (2) As a continuation of the Manila Tribune P1le, the Free Phil1ppines, Manila edition, provides Information regarding the I1beration of Manila since 1t was 1ssued after the Americans returned to Manila. Unfortunately 1t was not possible to secure the live copy of th1s flle but satisfactory arrangements were made for the Llbrary to borrow the paper for the purpose of making a microfilm copy. (3) The Leyte Sh1mbuny as far as I can discover the only Finglish newspaper Isoued by the Japanese on the Island of Leyte, was made avallable to the Llbrary by Mr. Fre1, Business Manager of the Presbyterlan M1ssion in the Philipplnes. As a Sw1ss cltizen and one keenly interested in publications dealing with the Ph1lippines, Mr. Frel found 1t possible to gather varlous publications lssued by the Japanese while he was in Leyte during the largest part of the war. It was he who had a complete flle of the PhilipPine Revlew, a monthly 1soued In Manila during the Japanese occupation which carried cultural information concerning, the Philippines as well as considerable war propaganda. T1 thin the serles appeared these art1cles: "R1zal the man"; "Tagalog through Japanese eyes"ly "Education under the Republic"; "Orlental ethics" and "The New Philipplne economy." Along with certain minor publications, he made these two 1mportant flles avallable to the Ilbrary in return for a mlorofiln copy of each plus a used set of the Encycopedia Bri.tannica (14th ed.u. Th1s exchange was sanctionec jy cable before the agreement was concluded.

Although there was not an enormous amount of publicatlons in the Tagalog language, all the 1mportent materlai lssued in Manila was secured. The re we re two main sources where these Tagalog books were avallable: the Un1varsity of Santo Tomas Press and certain bookstores which hancle primarliy materlal in this language. Fortunately I was abie to have the ald of Dr. Lopez, Prof. of Tagalog at the Un1versity of Ph1lippines, who accompanied me to those places where th1s vernacular materlal was located. While w1th Prof. Lopez, I learned that he had a large Filipinlana collection, but during the war all of $1 \mathrm{t}$ was destroyed by f1re. While at the Univers1ty of Santo Tomas Press, materlal other than Tagalog books was located in Ilocano Ibanag and Pangasinan languages. Th1s beling an lnstitution with a Spanish background, 1 was natural to find there a number of books published in the Span1sh languagew

Another source for materlals in the varlous languages of the Islands was the Ameurican Bible Soclety of which Mr. T. H. Fonger has been the Secretary for the past twenty years. 
Like all publishing and printing establishments, the Soclety was badly hit but not completely destroyed during the war. Elnce the war, all Tagalog and Ilocano Blbles have been printed in the U. S., and shipped to Manila for distribution. Plans are made for the production of Blbles in the Cebuano, Panayan, Blcolano, Samareno, Pangasinan and Pampangan languages-ail of wh1ch will be sent to the Ilbrary when avallable. One of the greatest losses of the Soclety during the war was the manuscript of the revised version of the ent1re Panayan Blbley whlch had been completted only a few months before the outbreak of the war in 1941. A copy of the New Testament portion of the manuscript was in New York but all coples of the old Testament portion were burned at Ilo1lo and Man1la. since Tagalog has been made the national language, plans are under way to make certain changes in the Tagalog B1ble so that 1t w1ll be acceptable to all groups.

The Inst1tute of Natlonal Language 1s an agency of the Ph1l1ppine Government created for the purpose of propagating the 1dea of Tagalog as the offlclal language in the Philippine Islands. Although the number of publications of the Institute have not been extensive since the war, the studies in the Tagalog Text Serles formerly 1 ssued before 1941 have been continued. One publication which will be of value to language students interested in Tagalog 18 The Propagation of the Filipino Language, 1ssued during the war in 1944.

Although no publications have been 1ssued by the newly organized PhIl1pplne H1storlcal Foundation of whlch Mr. Marcus P. Malupa is the Presidenty exchange arrangements were made to secure the Journal and other publications which will be 188 ued.

Since I was unable to v1s1t Dumaguete, arrangements were made by correspondence w1th Mr. William S1lliman for the Llbrary to recelve all publications lssued by the press at S1lliman University.

Franc1sco Zaragoza, a F1l1p1no collector of rare F111pinlana, showed me the fine collection of books on history, blbllography, pol1t1c8, phllology, religlon, travel, perlod1 cals and maps wh1ch had been gathered for many years of whlch fortunately not one volume was lost during the war. While at h1s residence, I discovered that the Ilbrary already had been informed of this valuable collection and a fully annotated catalog had been sent.

The Un1versity of Santo Tomas is the oldest university In the Ph1lippines and before the establishment of the RepubI1c 1t was the oldest UnIversity under the Amerlcan cllag. Through Rector Eugen1o Jordon and Norberto de Ramosy Registrar of the Unlversity, I learned that the University 18 an outgrowth of the early educational work inltiated by the Dominican order soon after their arrival in 1587 and was actually founded 
In 1611. Up unt1l the war a part of the Un1versity was maintalned on the original site in Intramuros, the Walled City, now In ruins, eg.u The Faculty of Medicine and Faculty of Law were formerly housed in the three-century old bullding which was completely destroyed during the battle for Manila in the days of the Liberation in February, 1945. The UnIversity Library is the oldest in the Philippines and contains many rare pleces of Flliplniana, 1nciuang books on H1story, Classlcal 11terature of many nations, Phllosophy and Religion, Sclences, Canon and C1vil Law as well as Incunabula. During the ent1re trip throughout Southeast Asla, the L1brary at Santo Tomas was the only one whlch was using the Llbrary of Congress Classiflcation system. For some years now Llbrary of Congress cards have been employed in the 1r cataloging department and the offlclal catalog. Mr. N1colas C. A. Fernandez, the Llbrarlan, expressed the need for a complete set of the L/C class1flcation manuals. There 1s a speclal need for the volume dealing with the $K$ classification since this 18 missing from the battered set now belng used. Through a conference w1th Rector Jordon an exchange agreement was established whe reby the Llbrary of Congress will recelve regularly from the Unlversity of Santo Tomas the following publications: Santo Tomas Journal of Medloine, lssued by the College of Medicine; Unitas, organ of the University Faculty; The Vars1tarlan, a fortn1ghtly in English 1soued by the studentsiuVoz Estudiantlal (VE), a fortnlghtly in Spanish losued by the studenti; of 1 clal addresses given annually at the opening exerclses of the academ1c year; University cataloge 18sued by different faculties rather than one comblned University catalog.

Although the damage sustalned by Phllipplne cultural Institutions during the war appeared to be extensive, the spirit of reconstruction manifested throughout Manila was encouraging. Although a c1ty of shambles in the fall of 1945, much has been cleaned up now. As a contrast to the c1ty of Batavia in the Indles, the re 1s certifled running water, electric l1ghts, and the sewage system functions satisfactorlly. Bulldings which were severely shelled or burned and left as standing skeletons throughout the c1ty are beling reconstructed everywhere. Near the C1ty Hall, which has been practically restored to 1 ts prewar appearance, 18 the National Library now belng rapldiy rebullt with high Government priority. Unt1l 1 ts completion, what few collectlons survived the war and the offlces of the National Library of the Philippines will continue to be housed in quarters in the Bllibld Prison. Every street has schools, churches, business houses or private dwellings belng rebullt; the sound of the saw and hammer and cement mixer never ccases. Reconstruction 18 the order of the day.

Following the reestablishment of the Commonwealth Government of the Ph111ppines in February, 1945, the Board of Regents of the Unlversity of the PhIllppines, which had been abollohed 
during the Japanese occupation, reconvened on June 21, 1945 and 1nstructed the President, Dr. Gonzalez, to reopen the war-ravaged Government institution within the shortest possible t1me under the best possible c1rcumstances.

It should not be assumed that the University did not function in some measure during the war perlod. Desplte the order of the late President Quezon to close the UnIversity on Dec. 13, 1941 and notw1thstanding the utilization of the Un1versity premlses and bulldings by the Japanese forces when they occupled Manila on January 2, 1942, sothe of the units of the 1nstitution remalned open becalise of the nature of their activities or the 1mortance of the $1 \mathrm{r}$ services to a nation at war. These units consisted of the Colleges of Agriculture, Medicine and Veterinary Solence as well as the Schouls of Dentistry, Forestry and Hyglene. Approximately $81 x$ months later the Japanese authorities perwit ted the operation of a Junlor College, ostensibly as a prcparatory school for the College of Mediclne but which actui.lly presented a limited number of courses, so that other students were enabled to continue their courses without interruption. By the end of 1942 the College of Englneering and the School of Pharmacy resumed their operations. According to Presldent Gonzales, the operation of the Unlversity during this perlod of constant survelllance by the Japanese M111tary Admin1stration was attended w1th numerous difflcult1esy and an atmosphere of repression pervaded the campus thwarting the sense of freedom in intellectual pursults whlch characterlzed the prewar days. By the t1me reports of the 1mminent invasion an recovery of the Ph1llpplnes by the Amerlcan forces seeped in, restlessness and fear manlfested 1 tself among the UnIversity personnel, and the act1vities of the Un1 versity were disrupted. S1 tuated south of the river whe re the Japanese took their final stand, the Unlversity campus was one of the places which suffered severely during the liberation of Manila. Some bulldings were a mass of rubble and tw1sted steel, others were badly shellpocked, and evidence of the gigantlc job of reconstruction was on every side.

Un1versity authorities returned to find their records, librarles, off $1 \mathrm{ces}$ and laboratorles and valuable sclent1flc equipment a total 108s. According to President Gonzales, a conservative est1mate based on original values would indicate a 1088 of about $\$ 5,000,000$. Since not a single bullding on the sampus was sultable for 1mmediate use, arrangements we re made w1 th the Inst1 tute for Radium Therapy for the reopening of the University on August, 1945, w1th an enrollment of approximately 2000 students, whlch was 25 per cent of the prewar number. Medicine, Liberal Arts, Englneering, Law and Education were among the Colleges reopened.

When the Japanese withdrew from the bulldings of the University at 1 ts new site at Diliman, Quezon C1ty, the bulldings were left in a deplorable condition. Construction on the 
Quezon C1ty site has not been resumed, since the U. S. Army has leased the property. Meanwhiley temporary repalrs have been made to the destroyed bulldings on the old campus to provide avallable classroom and offlce space. Some bulldings wh1ch I saw have been left in thelr badly damaged state, since 1t was considered unwise to repair them at all.

During the past year inflation in Manila has been quite acute and as a result the Unlversity was unable to extend 1 ts program or to correct the already low scale of salarles. Notwithstanding the physical and financlal difflsulties, high academic standards were malntainedo Sirce the independence of the Ph1l1ppines in July 1946, certain revisions were made in the varlous currioula, and within the past year the enrollment has increased to over 4000.

An Important part of the Un1versity resources wh1ch were wantonly burned by the Japanese during the flght for 11beration were the valuable materlals in the University Library. In May 1941 these holdings cons18ted of approximately 144,000 books and 71,000 other pleces--perlodicaI t1tles, maps, manuscrlpts, muslc scores, eto. Rehabilitation of the Iilbrary started w1th what could be salvaged as well as w1th those books wh1ch were procured by g1ft and depository concession; c1rcumstances in 1945 prevented purchases and exchange activities. Both President Gonzales and Prof. Bernardo, the Llbrartan, expressed their deep appreolation of the ald whioh the L1brary of Congress has continued to give sinoe the first days of the rehabli1tation. Hundreds and hundreds of U. $S_{\text {. documents wh1ch }}$ had been stookplled in the Llbrary of Congress, the accumulation of the war years since 1941, were sent from Washington to the University of the Ph1l1ppines L1brary. L1kew1se, gifts were liberally made by the American Library Assoclation, the U. S. Amy, and private 1ndividuals.

A vital unit of the University L1brary 18 the Joseph Raluston Hayden Memorlal Library. The nuoleus of th1s 11 brary came from The Ph1l1ppine Researoh and Information Section, USAFFE, operated by Dr. Hayden and It. M1llegan. S1nce this Service gathered twenty-f1ve sets of all materlal published in the Ph1l1ppines during the Japanese occupation, the Univers1ty L1brary was most fortunate when 1t was proposed by Lt. Millegan that a Memorlal Library, as a living monument to the memory of the late Dr. Hayden, be established and located at the Unlversity of the Ph1lipplnes. As a result, the master collection-one of the four most complete sets--was placed in th1s Memorlal Llbrary at the University where Prof. Gabriel Bernardo 18 the able Llbrarlan. It 18 hoped that the Hayden Memorlal Llbrary w1ll become a national center of research and information on Filipino-American relations as well as International Llbrary Center in the Far East for promoting international library coordination and standardination through (I) b1bllograph1c and library information and (2) internathonal exchange of Ilbrary personse 1 and publicationsu 
One of the most valuable collections of Filipiniana 18 located at the Museum and Inst1tute of Archaeology and Ethnology in the Unlversity of the PhIllppines. Although there was a larger collection before the war, it is reported now that there are 5000 volumes, 15,000 pamphlets, 3,500 prints and 5000 manuscripts. Two outstanding collections in th1s materlal are (1) the unpublished typewritten manusarints dealing with ethnology of the PhIlipplnes and popularly irow as the Beyer collection; and (2) the collection of Japane materlal published in the Phllippines during the war. Fortunately the majorlty of the manuscripts were preserved in the war years, since Prof. Beyer was granted speclal perm1ssion through the influence of a Japanese sclent1st frlend to move the materlals from the Unlversity campus to the bullding at 506 Av1les Street in whlch they are now housed. The large collection of Japanese materlal came about because after the liberation the Government put Prof. Beyer in charge of salvagIng the Japanese publications whlch were stored largely in one bullding. Since the war there has been nelther time nor sufflclent staff to place the books on the shelves in their proper order; also, no record has been prepared as to what titles exist in the collection. Herein lies one of the chlef reasons why such valuable documents should be f1lmed. Wrile I was visiting on several occaslons with this outstanding scholar and authority of anthropology in the Phillppines, several writings of Prof. Beyer wire given to the Library. One of the most interesting books secured in the PhIllppines 1s ent1tled Ph1lipdine Saea: A P1ctorlal H1story of the Archlpelago Sirice Time Began (1947\%). The copy g1ven to the IIbrary Includes the handwritten corrections by the author, Dr. Beyer. Other writings 1nclide: Orlgin Myths from Bhilippine Mountain Peoples, in monograph form, a paper read jefore the PhIIIppine Academy as one of the flrst studies of PhIllppine mythology and religion; Pageant at the Man1la Cam1val Commerclal and Industrial Falr which represents conditions at the court of three Moro Rajas who, at the time of the arrival now Man1la; and Phlilppine Tekt1tes. In order to comple te the set of the Beyer Hellemam manuscripts which the I 1brary of Congress now has, Index volume 10 will be $g^{1}$ ven to the Llbrary since he had an extra copy.

According to a letter from Prof. Bermardo, the University of the PhIllppines will be pleased to continue the prewar exchange agreement by sending the Llbrary the following publicatlons which have been 1soued since the war, The Phllipplne Law Journal, The Un1versity Code, The Un1versity Catalog, The President s Reports. As so on as the following prewar'pubilactions are resumed, they too w1ll be sent; The Philippine Soclal Sclence Review, Natural and Applied dclence Bullet1n, The Phillpplne CollegIan ard The PhIl1pplnensian. AIthough the NatIonal Fesearch Counoll of the Philippines Is not a constituent part of the University, efforts will be exerted to have a copy of 
1 ts publications sent to the Llbrary. When present plans for 1souing a Ph1l1ppine B1bllographical Bulletin are fulfilled, this publication w1ll also come to the Library.

Of all the places visited in Southeast Asla, the PhIllppines had the richest possibilities for the Ilbrary of Congress' securlng microfllm coples of those books, manuscripts and maps whlch the Llbrary does not have at present. The chlef sources of th1s materlal dealing w1th the Phllippines are located at the UnIversity of the Ph1llppines I1brary, The University of Santo Tomas Library and Muselm, the Bureau of National Librarles and the 8o-called Beyer Collection in the Department of Anthropology of the University of the PhIlippines. It was a disappointment not to be able to be in Manila at the time Mr. Fahs from the Rockefeller Foundation was there in conference w1th President Gonzales, Prof. Bernardo, Prof. Beyer and others for the purpose of establishing some kind of an agreement whereby the Foundation would provide the University of the Ph1lippines with m1crofllm equipment in exchange for coples of the materlal wh1ch has survived the war. A verbal statement was made to Professors Beyer and Bernardo that the Ilbrary of Congress is prepared with microfllm equipment to carry out an international exchange of Filipiniana in microf1lm and photostat form. In th1s manner, the L1brary of Congress might secure materlal which for some reason we have not procured in the past, and different institutiors in Manila can replace valuable materlals whlch they lost during the war.

Mile in Manila, the followling addresses were delivered on behalf of the Llbrary (1) a radio talk over the Government station KZFM, one Saturday even 1ng, "Acquisition of F1l1piniana for the Ilbrary of Congress.tH (2) Under the ausplces of the Department of Library of Sclence in conjunction with the 34 th Commencement Exercises of the Un1veralty, a talk was given to the students and faculty. During the program three films regarding librarles in America were shown, including one in color on the Ilbrary of Congress. (3) "The Services of the I1brary of Congress" was the toplc used when speaking before the Ph1l1ppine Library Assoclation at the National L1brary. Mr. Rodrlque $z^{\prime}$ introduction included the fact that 1t was the f1rst time a person from an Amerlcan Library had spoken to their Assoclation. Because of the 1nquirles of two Senators present there was considerable interest shown in the Leg1slat1 ve Reference Service; the group as a whole was interested in the microfilm services made avallable to the publicla

I w1ll not forget the late afternoon of Tuesday, April 13th, when-by speclal 1nvitation from Prealient Gonzalug--I was privileged to hear President Roxas aellver the add:ors at the 34 th commencement of the Unlversity, one of the last public appearances of the national leader prior to his sudden death only two days later. The oocasion took place outslde in the largest quadrangle with the war battered bulldings on all 
s1des. Standing bareheaded in a drenching rain which continued throughout the ceremonies, the President addressed the graduating class of 348 students, w1th a simple but 1mportant message to a people who had just come through a terrible war perlod: the need for an actlve particlpation on the part of all Filipino" people "In a national crusade for moral regenerat1on.en

My last week in Man1la was marked by the atmosphere of mourning. Flags were flown at half-mast and Government offlces, business f1rms and schools throughout the cap1tal operated only part-time so that offlclals, employees and school ch1ldren could go to Malacanan to pay the1r last respects to the f1rst President of the1r Republic. Even radio stations ellminated all commerclal announcements from the1r broadcasts. V1g1l over the body of the President was kept by varlous offlclals of the Government. I too reallzed that an 1mportant and capable leader in the Orlent had been taken away. 


\section{SUMMARY}

I. Acquisition objectives.

1. To arrange for international exchange of Government publications.

2. To arrange for exchange of publications between the Library and colleges, universities, research societies and other institutions.

3. To procure by subscription and exchange all important newspapers and other serial publications.

4. To purchase books and other matexials published prior to and since the war.

5. To acquire all available books, newspapers and journals issued by the Japanese during their occupation of Southeast Asia.

6. To engage reliable bookdealers as agents for the Library.

7. To gather information pertinent to the Law Library, the Division of maps and other Divisions of the Library.

\section{Exchange agreements}

A. Offèciale

1. With Burma (p.10) and Philippines (p.e37-8) -- by exchange of offeiclal notes.

2. With Federation of Malaya (p. 18-20), Colony of Singapore ( $p$. 18-19), East Indies (29-30-1) and Indochina (p.32-3)--on an informal basis.

3. With Slam (p.7-8)--by a formal agreement concluded prior to visit.

B. Institutional and others

1. National Library of Siam (, 7 )

2. Chulaloagkorn University, Bangkok (p. 8 )

3. Viet Nam News Serviceg Bangkok ( $p .8$ )

4. Siam Society, Bangkok (p. 9 )

5. Malayan Law Journal, Singapore (p,18)

6. Rubber Research Institute, Kuala Lumpur (p29)

7. Institute for Medical Research, Kuala Lumpur (p. 20)

8. South Seas Society, Singapore (p.2l)

9. Indonesian News Service, Kuala Lumpur (p.21)

10. Malayan Nature Society, Kual.a Lumpur (p.2l)

11. Foresters Society, Kuala Lumpur (p.e2l-2e)

12. Malayan Teachers' Union, Singapore $(p, 22)$

13. Raffles Museum, Singapore ( $p .22$ )

14. Malayan Branch Royal Asiatic Society, Singapore (p. 22 )

15. Raffles College, Singapore ( $p, 22$ )

16. Antara News Agency, Jogjakarta ( $p_{0} 25$ )

17. Aneta News Agency, Batavia (p.28)

18. Indonesian Information Service, Batavia (, 23 )

19. Koninklijk Bataviasch Genootschap van Kunsten en Wetenschappen (p. 27 )

20. Central Library of Natural Science, Buitenzorg (p.e2t

21. Muses Blanchard de la Brosse, Salgca (p. 32 ) 
22. Societe des Etudes Indochinoises, Saigon (p. 32)

23. Universitie de I'Indochine, Saigon and Hanoi (p. $33,35-6)$

24. Archives et des Bibliotheques de I'Indochine, Saigon and Hanoi (p. 33-6)

25. France-Asie, Saigon (p.33-4)

26. Ecole Francaise d'Extreme Orient, Hanoi (p. 34-6)

27. Institute of National Language, Manila ( $p_{0} 42$ )

28. Philippine Historical Foundation, Manila (p. 41 )

29. University of Santa Tomes, Manila ( $p_{0} 41$ )

30. University of the Philippines, Manila ( $p_{0} 42$ )

III. Current Newspapers and Periodicals Secured.

A. Siam

1. Newspapers and News Bulle tins: Bangkok Post, Liberty, Standard; Norkorn Sarn, Sajja, Siam Nikorn.

2. Periodicals: Journal of Siam Society, Natural History Bulletin, Law Journal of Siam, Jomrnal of Medical Association of Siam; Siam Trade and Economic Review, Pharmaceutical Journal.

B. Burma

1. Newspapers: New Times of Burma, the Burman, Burmese Review, Oway and Mansa Alim (New Light of Burma).

C. Malaya

1. Newspapers and News Bulletins: Straits Times, Sunday Times, Singapore Free Press, Malaya Tribune, Economic Melayu, Sulah Kemajuan, Dunia Baharu, Straits Echo, Sunday Gazette, Chermin Melayu, Varthazani, Indonesian News Bulle tin;

2. Periodicals: Maleyan Lai Journal, Malayan Pictorial Observer, Bulletin of Institute for Medical Research, Journal of South Seas Society, Nanyang Miscellany, Journal of Malayan Nature Society, Malayan Educator, Malayan Agricultural Journal, the Forester, Medical Journal of Malaya, Journal of the Raffles Museum, Journal of the Malayan Branch Royal Asiatic Society.

D. East Indies

1. Newspapers and News Bulletins: Antara News Bulletin, Aneta News Bulletin, Het Dagblad, Merdeka, Nieuwa Courant, Niewsgier.

2. Periodicals: Bulletin Koninkj.ijk Bataviaasch Genootschap van Kunsten en Wetenschap ren, Bulletin of Bureau of Mines and Geologicel Survey in Indonesia, Economic Review of Indonesia; Bulletin of the Botanic Gardens, Treubia, Annals of the Botanic Gardens, Our World, DiOrient, Iadische Finencier, Nanyang Post, Pembarosan, Soeloch Warta, Voice of Indonesia.

E. Indochina. 
1. Newspapers and News Bulletins: Journal de Saigon, Lo Populaire, L:Echo de Viet Nam, Revue de la Presse Vietnamienne et Chinoise.

2. Periodicals: Bulletin Societe des Etudes Indochinoises; Educa.tion, France-Asia, Journal Jndiciare de I'Indochlne, Bulletin Ecole Francaise d'Bxtreme Orient, Bulletin l'Imstitut Indochinois peur l'Etude de l'Hommo,

F. Philippine Islands

1. Newspapers: Manila Chronicle, Manila Daily Bulletin, Manila Times, Bagong Buhay, Bisaya, Fockien Times, Bicol Independent, Nalmibag A Damag Ken Ti Dalen, Pioneer Press, Yuhum

2. Periodicals: American Chame of Commerce Journal, Business Digest and Buyers Guide, Commerce, Jourtal of Philippine Commerce Magazine, Philippine Digest, Philippine Educator, Philippine Medical World, Philippine Trends: Philippine Outlook, Sugar News, Ang Manughantala, Ang Catarungan, AgriculturalCommercial Industrial Life, Industrial Outlook, Philipnine Law Journal, Unitas, Santa Tomes Journal of Medicine.

G. Lists have been compiled of the newspapers nd periodicals being published in each of the above count ries.

IV. Outstanding Acguisitions

1. Comple te set of Siamese laws and enactments in Siamese 58 vols. (p. 4$)$.

2. Complete set of Siamese Parliamentary Debates (p. le)

3. Significant books dealing with Buddhism in Burma (p.Ir')

4. Books on Burmese Law ( $p_{0} 20$ )

5. Comple te file of Syonan Shimbun, issued by Japanese in Singapore ( 0.16 )

6. Complete file of Straits Times, Sunday Times and singapore Free Press issued since Iiberation, 1945. (p.16.29).

7. Acts and Ordinances of Legislative Council of Straits Settlements $(\mathrm{p}, 28)$

8. Publications issuea by Republican Government at Jogjakarta (p.24-5).

9. Album of Republican propaganda posters in miniature (p. 24)

10. Proceedings of West Java State Conference ( $p_{0} 20$ )

11. Proceedings of official conference considering the Indonestan question (p. 30 ).

12. Complete file of Manila Trivane, issued by Japanese (p. 39-4d

13. Complete file of texte Shichun $1912-3$ (p. 40 )

14. The Beyster Beport ( 1,30$)$

16. The Philippine Sago (p. 45)

16. Copies of the Constitutions of all Southeast Asia countries.

17. Summary bulletins of the vernacular press in the various countries. 


\section{Bookdealer Apentes Engaged}

1. Siam: Niboadh, New Road, Sikak Phya Sri, Bangkok (p. 5 )

2. Burina: Educational Bookstore, Merchant Street, Rangoon (p. 11 )

3. Singapore and Malaya: Kelly and Walsh, Raffles Place, Singapore ( $p \cdot 17-8)$

4. East Indies: Kolff and Co., Batavia ( .26 )

5. Indochina: A. Portail and Cou, Rue Catinat, Saigon (p. 36 )

6. Philippines: Advocate Book Supply Co.e Azcarrage Street, Manila (p. 38-39)

N.B. A list has been compiled of the leading bookdealers in each of the above mentioned countries.

VI. Amount spent for purchases (close estimates)

\begin{tabular}{ccccc}
\hline 1. Siam: $\$ 950$ & 3. & Malaya: $\$ 819$ & 5. Indochina: & $\$ 262$ \\
2. Burma: $\$ 600$ & 4. E.Incies $\$ 181$ & 6. Philippines & $\$ 634$ \\
& Estimated total: & $\$ 4045$
\end{tabular}

Letter of credit nos.: $9559 \mathrm{G}$ and 75366

VII. General observations

1. In everye ceuntry there was considerable interest shown in the microfilm idea and its availability at the Library of Congress. Many persons placed requests for information concerning the necessary equipment to set up microfilm facilities.\$p. 27-35)

2. It was discovered in different places that various universities, libraries and individuals had materials which ought to be filmed. Three are cited: The Damrong Collection in Bangkok ( .2 .3$)$ ), The Oriental material in the library of Ecole Francaise at Hanoi (p.35-6) and the sowoalled Beyer Colja ction at the University of the Philippines (p. 45-se.

3. Of all the Library of Congress publications which were distributed in conjunction with exchange and other occasions, the United States Quarterly Book List was highly preferred. Interest was also high in all bibliographloal publicatione..

4. Considerable information was secured which will be of special interest to the Law Library ( $p .4,5,13-17,16-33,30$ ) and the Division of Maps (p. 8-9, 14-19-26-34).

5. In order to aid in the process of rehabilitation following the extensive destruction caised by the war, the Cumulative Catialog of L/C Printed C-rds might be placed in key research institutions in each of the countries of Southeast Asia. Considerable interest was shown in the publication since it was looked upon as a valuable tool with which to rebuild research collections.

6. There appears to be a trend in Burms to publish most, if not all, of ficial documents in the Burmese language ( $\left.p, I_{t}\right)$.

7. As an asset for cataloging works from these countriese 1nformation was gathered with reference to the usage and classification of proper names ( $p_{3} 33$ ).

8. Among the institutions visited, the University of the Philippines was the worst hit by the war (p. 42-3). 